\title{
Hydrolysis of Scandium Alkyl Derivatives Supported by a Pentadentate Diborate Ligand: Interconversion of Hydroxo and Oxo Complexes. ${ }^{\perp}$
}

\author{
Daniel W. Beh, ${ }^{\dagger}$ Warren E. Piers, ${ }^{\dagger *}$ Laurent Maron, ${ }^{\dagger}$ Yan Yang, ${ }^{\dagger}$ Benjamin S. Gelfand ${ }^{\dagger}$ and Jian-

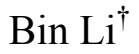 \\ ${ }^{\dagger}$ Department of Chemistry, University of Calgary, 2500 University Drive NW, \\ Calgary, Alberta, Canada T2N 1N4 \\ ${ }^{\ddagger}$ LPCNO, Université de Toulouse, INSA, UPS, LPCNO, 135 avenue de Rangueil, F- 31077 \\ Toulouse, France, and CNRS, LPCNO, F-31077 Toulouse, France
}

*Corresponding Author. Email Address: wpiers@ucalgary.ca

\begin{abstract}
Uncontrolled reaction of water with scandium alkyls (compounds 1-R) supported by a dianionic, pentadentate ligand leads to rapid formation of an oxo-bridged dimer (2). Solid state samples can be exposed to ambient atmosphere to generate samples enriched in the bridging dihydroxo dimer $\mathbf{3}$, which slowly converts to the $\mu$-oxo species with elimination of water. DFT computations show that $\mathbf{3}$ is actually more thermodynamically stable than $\mathbf{2}$, but the reactivity of 3 with the water eliminated leads to its decomposition to $\mathbf{2}$ and several hydrolysis products. Some of these products were characterized by X-ray crystallography, specifically a hexameric scandium dihydroxo cluster (4) in which the pentadentate ligand has partially demetallated. Attempts to synthesize hydroxo complex $\mathbf{3}$ by protonation of $\mathbf{2}$ also lead to hydrolysis products.
\end{abstract}

\section{Graphical Abstract}

Dedicated to Prof. John E. Bercaw on the occasion of his $75^{\text {th }}$ birthday. 


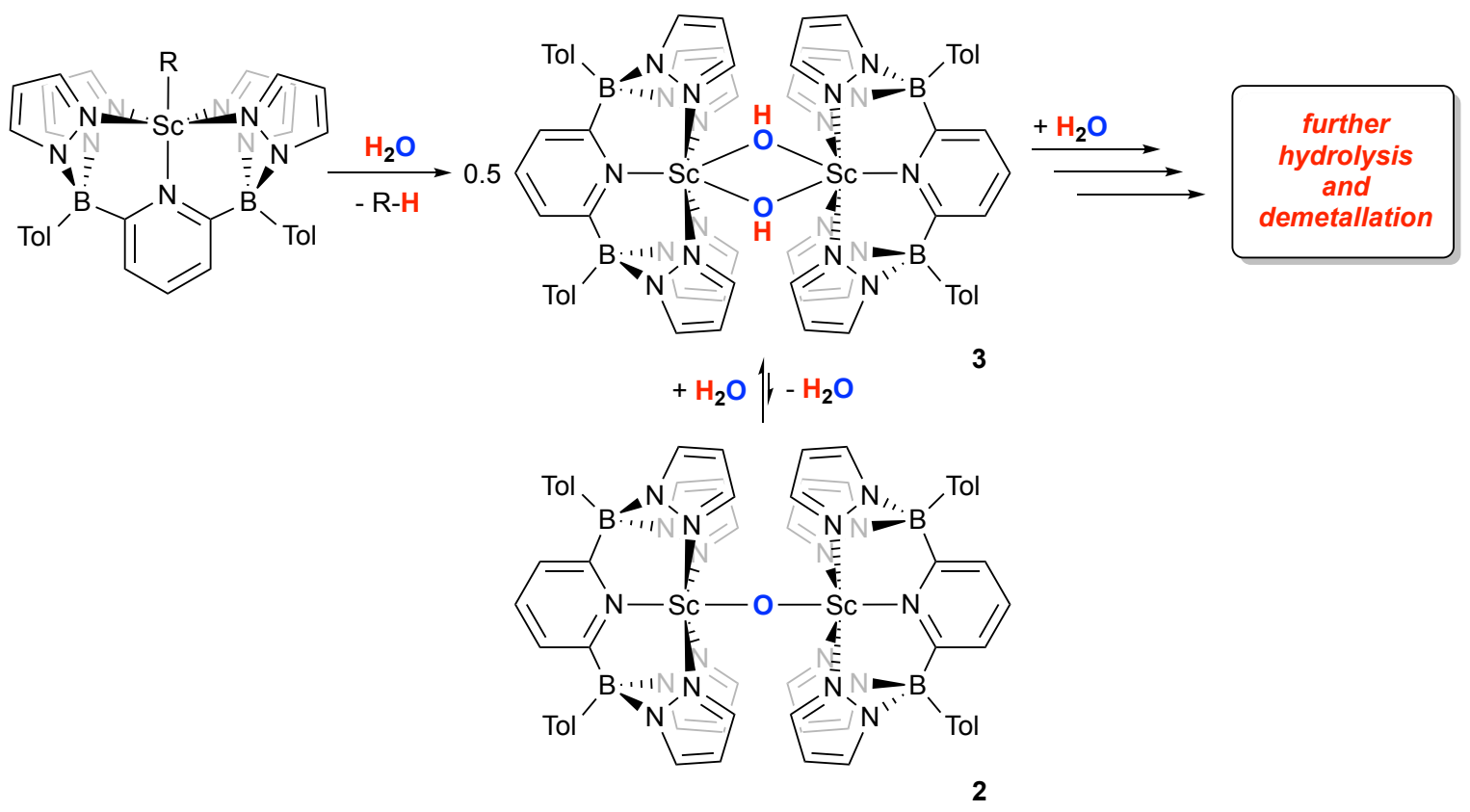

\section{Keywords}

Scandium, pentadentate ligand, hydrolysis, metal hydroxos, metal oxos

\section{Introduction}

Well-defined terminal hydroxo complexes of the group 3 transition metals are rare[1] due to the high tendency of the hydroxo ligand to assume bridging bonding motifs because of their Lewis acidity, oxophilicity and predilection for high coordination numbers. The stability of early metal oxo compounds also makes the $\mathrm{M}-\mathrm{OH}$ protons relatively acidic and kinetically unstable toward formation of bridging oxo complexes. Nonetheless, if isolable, such terminal $\mathrm{L}_{\mathrm{n}} \mathrm{M}-\mathrm{OH}$ compounds can potentially serve as useful synthons for the formation of $L_{n} M-O-M^{\prime} L_{n}$ complexes[2,3] which are of interest particularly when $\mathrm{M} \neq \mathrm{M}^{\prime}$. Thus, there is interest in finding routes to such terminal metal hydroxos. For the early transition metals, this has mostly relied on controlled hydrolysis of metal alkyls, hydrides, or amides (Scheme 1).[4-8] However, the aforementioned acidity of the desired $\mathrm{L}_{\mathrm{n}} \mathrm{M}-\mathrm{OH}$ complex often renders the rate of the second step 
competitive with the first, and the $\mu$-oxo complex is often favoured both kinetically and thermodynamically.

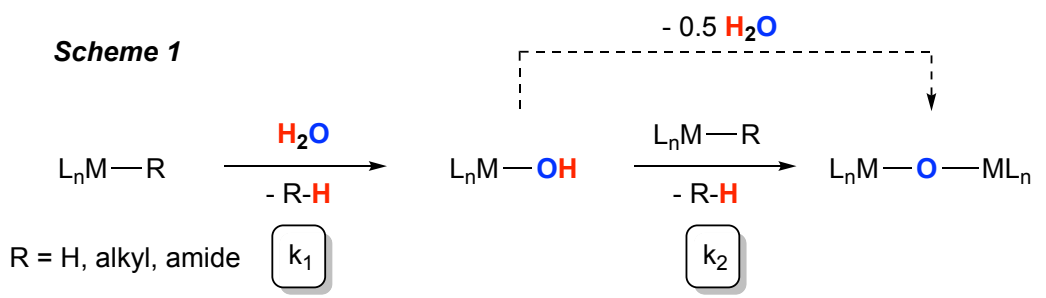

We recently reported a family of scandium alkyl complexes, 1-R, supported by a dianionic, pentadentate ligand system, $\mathrm{B}_{2} \mathrm{Pz}_{4} \mathrm{Py}$ (Scheme 2).[9] These compounds have remarkable thermal stability and resistance to sigma bond metathesis reactions[10] common in, for example,

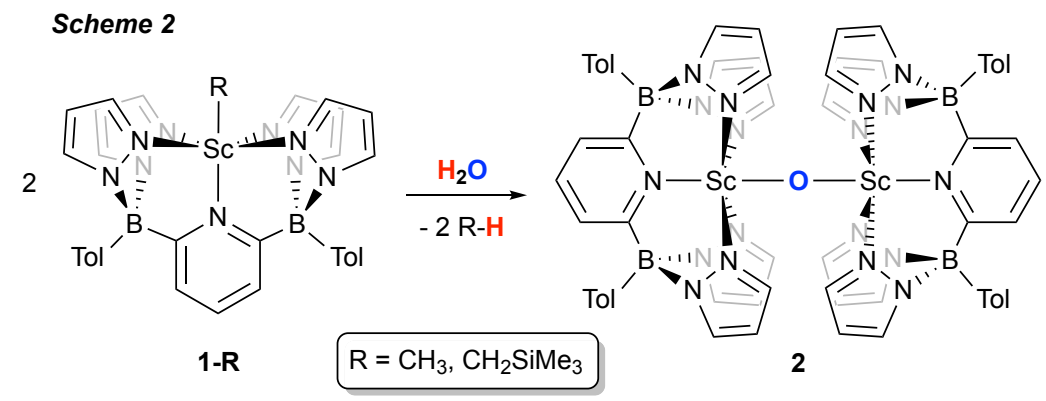

decamethylscandocene alkyls.[11] However, they are highly reactive towards protic reagents, including trace amounts of water. The product of this reaction is the Sc-O-Sc complex 2. We were interested in the possibility of preparing a scandium hydroxo compound on this platform and have explored the controlled hydrolysis of compounds $1-\mathrm{R}\left(\mathrm{R}=\mathrm{CH}_{3}\right.$ and $\left.\mathrm{CH}_{2} \mathrm{SiMe}_{3}\right)$; the results of these studies are described herein.

\section{Results and Discussion}

Several attempts to favour formation of a scandium hydroxo complex $\left[\left(\mathrm{B}_{2} \mathrm{Pz} \mathrm{z}_{4} \mathrm{Py}\right) \mathrm{ScOH}\right]_{\mathrm{n}}$ through controlled reaction of the scandium alkyl $\mathbf{1 - C \mathbf { H } _ { 2 }} \mathrm{SiMe}_{3}$ with water in toluene solution 
were not successful. Reaction conditions were varied according to the equivalents of water added (stoichiometric to excess), the temperature of the reaction (RT to $-20^{\circ} \mathrm{C}$ ) and the solvent (toluene, THF) and in all cases, the $\mu$-oxo complex 2 was the sole or dominant scandiumcontaining product. However, when solid samples of analytically pure 1- $\mathbf{C H}_{2} \mathbf{S i M e}_{3}$ were removed from an inert atmosphere glove box and exposed to atmosphere for 5-10 minutes and then returned to the glove box for spectroscopic analysis, two products were in evidence (Figure 1). All of the scandium alkyl was consumed, and 2 was observed as one of the products (40$50 \%$ ) but a second, new product was also present, seen as a separate set of ligand resonances and a distinct peak at $5.47 \mathrm{ppm}$, integrating to one proton in relation to the single para-pyridyl proton for this new species (Figure 1).

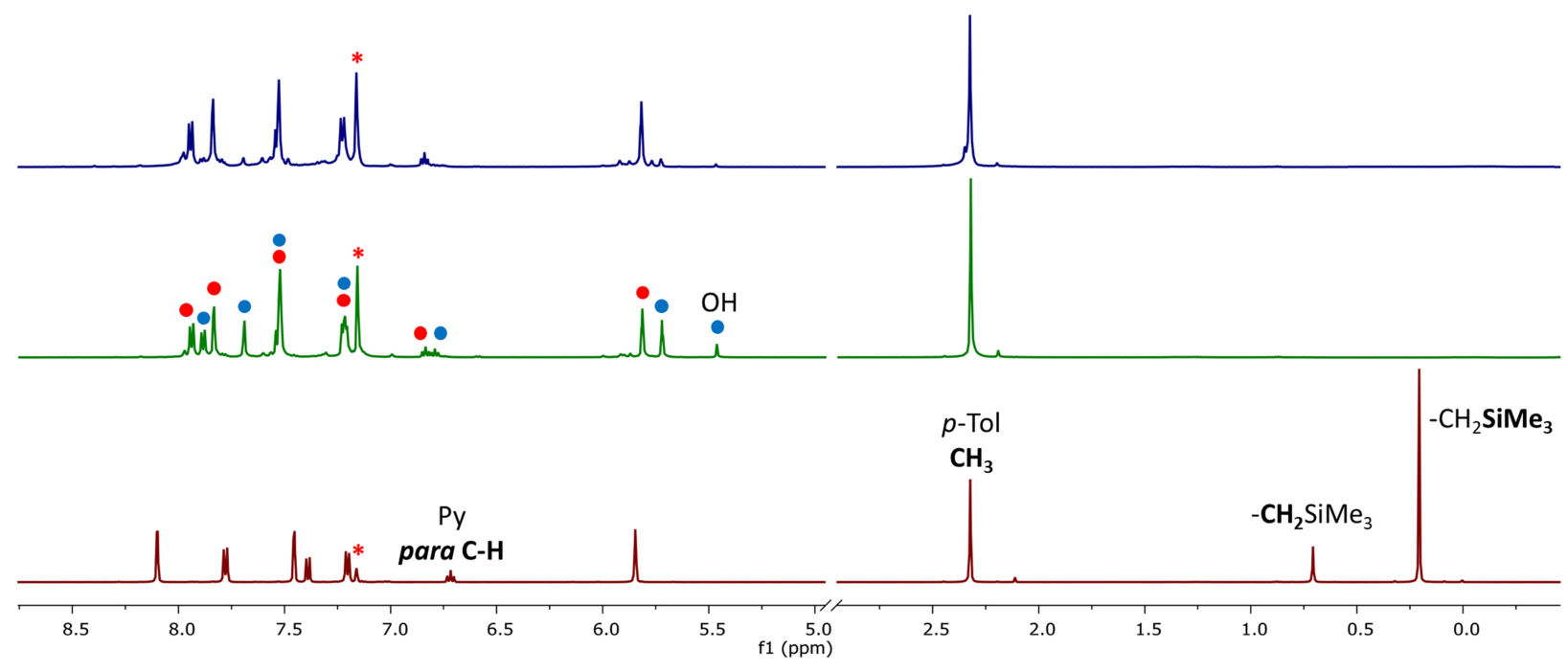

Figure 1. ${ }^{1} \mathrm{H}$ NMR spectrum of an independent sample of $\left(\mathrm{B}_{2} \mathrm{Pz}_{4} \mathrm{Py}\right) \mathrm{ScCH}_{2} \mathrm{SiMe}_{3}$ for reference (bottom), in contrast to the resulting spectrum by exposing a solid sample of the scandium alkyl complex to air for 10 mins (middle). Ligand resonances for compounds $\mathbf{2}$ and $\mathbf{3}$ are identified by red and blue dots respectively. Heating the solution to $50{ }^{\circ} \mathrm{C}$ over a few hours led to the disappearance of $\mathbf{3}$ and only complex $\mathbf{2}$ remained (top). Solvent residual signal indicated with an asterisk. 
Redissolved samples prepared in this way were relatively static at room temperature in terms of the ratio of $\mathbf{2}$ to the new product; crystals grown from this mixture were analyzed by X-ray crystallography, and the new product was identified as the dimeric hydroxo species $\left[\left(\mathrm{B}_{2} \mathrm{Pz} 4 \mathrm{Py}\right) \mathrm{Sc}(\mu-\mathrm{OH})\right]_{2}, 3$. A thermal ellipsoid diagram of the compound is shown in Figure 2.

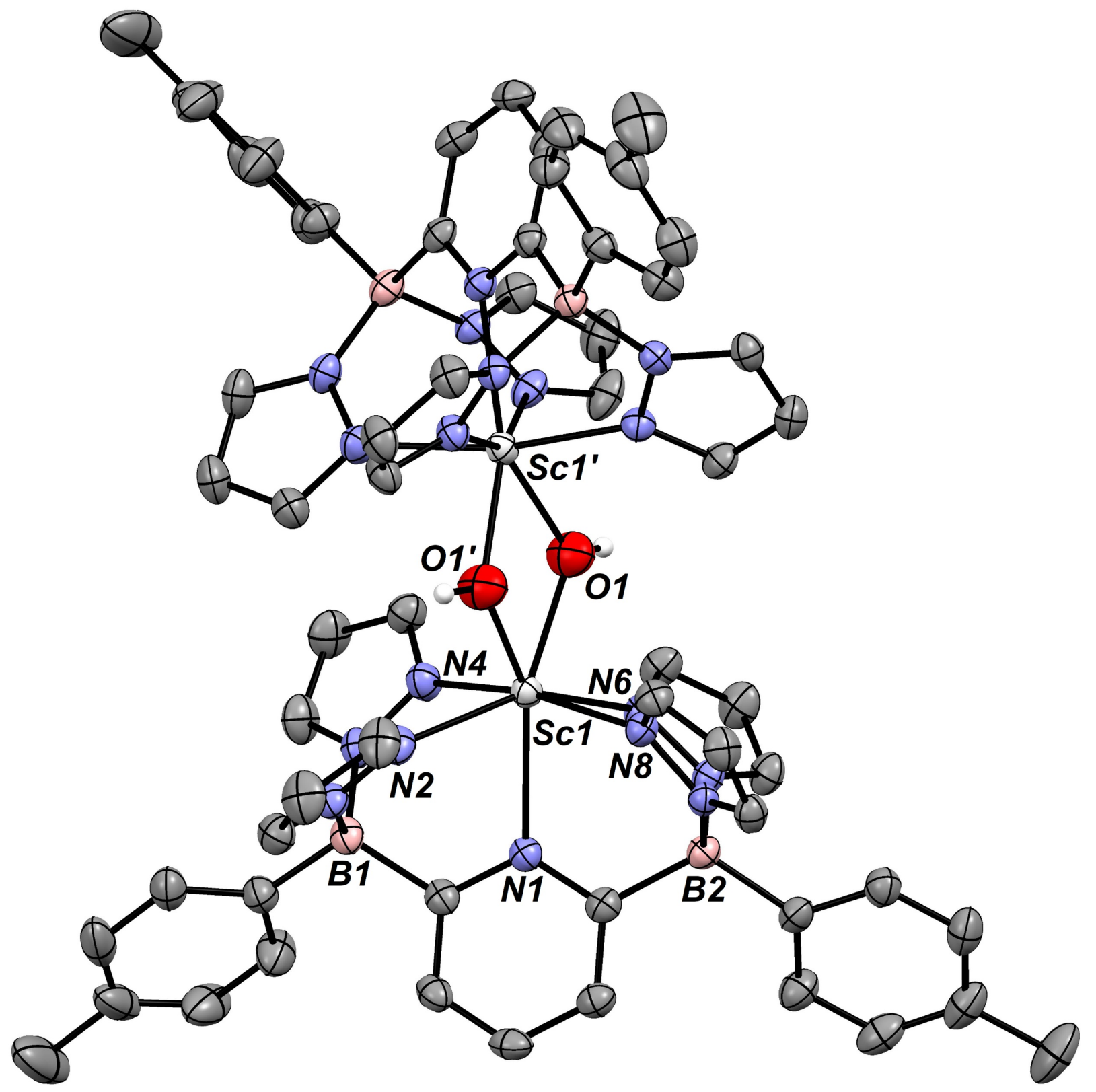

Figure 2. Molecular structure of 3. Most hydrogen atoms have been omitted for clarity. Thermal ellipsoids are shown at the $50 \%$ probability level. Selected bond lengths $(\AA)$ and angles $\left({ }^{\circ}\right)$ : Sc1- 
N1, 2.404(2); Sc1-N2, 2.312(2); Sc1-N4, 2.206(2); Sc1-N6, 2.252(2); Sc1-N8, 2.231(2); Sc1O1, 2.118(3); Sc1-O1', 2.196(3); Sc1‥Sc1', 3.6157(5); N2-Sc1-N8, 101.96(6); N2-Sc1-N4, 81.34(7); N4-Sc1-N6, 90.61(7); N6-Sc1-N8, 80.61(6); O1-Sc1-O1', 64.9(1); Sc1-O1-Sc1', $113.8(1)$.

Structurally characterized scandium hydroxo compounds are relatively rare and often are secondary products that result from prolonged crystallizations.[12-16] Using porphyrin[17] or salen[12] ligands, reproducible routes to hydroxo derivatives involving reaction of water with scandium amido complexes were developed. In all cases, the $\mathrm{L}_{n} \mathrm{Sc}-\mathrm{OH}$ compounds are multinuclear, usually dimeric, and despite the pentadentate nature of the $\mathrm{B}_{2} \mathrm{Pz}_{4} \mathrm{Py}$ ligand, compound $\mathbf{3}$ is no different. The molecular structure of $\mathbf{3}$ depicted features $\mathrm{Sc}-\mathrm{O}$ bonds of 2.118(3) and 2.196(3) $\AA$, and an O1-Sc1-O1' bond angle of 64.9(1) ${ }^{\circ}$; these are comparable with other scandium $\mu-\mathrm{OH}$ dimers. ${ }^{\ddagger}$ An $\mathrm{O}-\mathrm{H}$ stretch was observed at $3716 \mathrm{~cm}^{-1}$ in the solid state IR spectrum which is in line with a $[\mathrm{Sc}(\mu-\mathrm{OH})]_{2}$ moiety [12]. DOSY NMR experiments indicate that the dimeric structure of $\mathbf{3}$ is maintained in benzene solution (Figure S2). Analysis of an $\approx 1:$ 1 mixture of $\mathbf{2}$ and $\mathbf{3}$ prepared with this methodology indicated very similar diffusion constants (and therefore hydrodynamic radii), distinctly different from the parameters found for $\mathbf{1}-\mathbf{C H}_{\mathbf{3}}$.[9]

\footnotetext{
* From the CCDC accessed on 23 April 2019, the average Sc-O bond distance in 40 hits for Sc $\mu$-OH dimer is $2.072 \AA$. The bond lengths range from 2.033 to $2.117 \AA$. Average $\mathrm{O}-\mathrm{Sc}-\mathrm{O}$ bond angle is $73.6^{\circ}$ ranging from 69.4 to $78.4^{\circ}$, while the average $\mathrm{Sc}-\mathrm{O}-\mathrm{Sc}$ bond angle is $107.5^{\circ}$ ranging from 101.6 to $111.3^{\circ}$.
} 


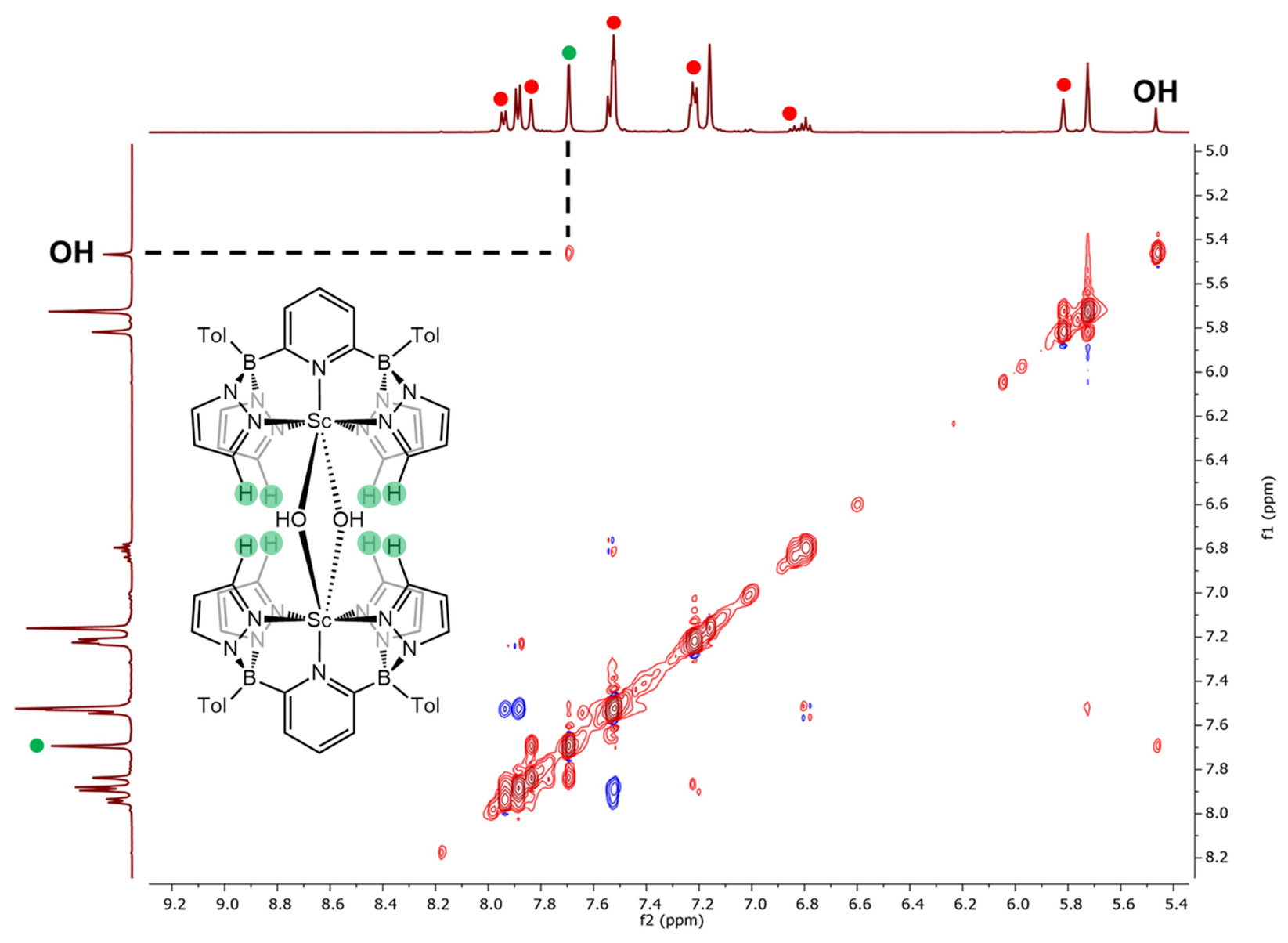

Figure 3. 2D NOESY spectrum of the mixture of 2 and 3 in $\mathrm{C}_{6} \mathrm{D}_{6}$. Through space correlation between pyrazolyl protons (green dots) and hydroxyl proton in $\mathbf{3}$ is indicated by dashed lines. Red dots represent ligand resonances for 2.

Furthermore, the dimeric nature of $\mathbf{3}$ in solution was supported by a nuclear Overhauser effect spectroscopy (NOESY) experiment in which through space correlation was observed between the hydroxyl proton at $5.47 \mathrm{ppm}$ and the pyrazolyl protons on the 3-position of the pyrazole rings at $7.69 \mathrm{ppm}$ (Figure 3). A monomeric hydroxide would likely place these protons at a greater distance from each other and so the strong correlation is suggestive of the observed dimeric structure. 
The reaction of solid samples of $\mathbf{1}-\mathbf{C H}_{2} \mathbf{S i M e}$ with atmospheric water thus appears to proceed to a mixture of $\mathbf{2}$ and $\mathbf{3}$ (Scheme 3). When samples prepared in this way are heated gently to $50^{\circ} \mathrm{C}$ (or allowed to remain at room temperature for several days), eventually $\mathbf{3}$ disappears and $\mathbf{2}$ dominates in solution (Figure 1, top). Small amounts of another species is in evidence, and crystals grown from these samples reveal the presence of another compound, $\mathbf{4}$, that is formally the product of the reaction of $\mathbf{3}$ with $\mathrm{H}_{2} \mathrm{O}$. Presumably, the water formed via condensation of $\mathbf{3}$ to form $\mathbf{2}$ can react with 3 to yield $\mathbf{4}$. Compound $\mathbf{4}$ results from protonation of the pyridyl nitrogen of the $\mathrm{B}_{2} \mathrm{Pz}_{4} \mathrm{Py}$ ligand in $\mathbf{3}$, resulting in a scandium dihydroxo unit which crystallizes out as a (rather beautiful) hexameric structure as depicted in Figure 4.

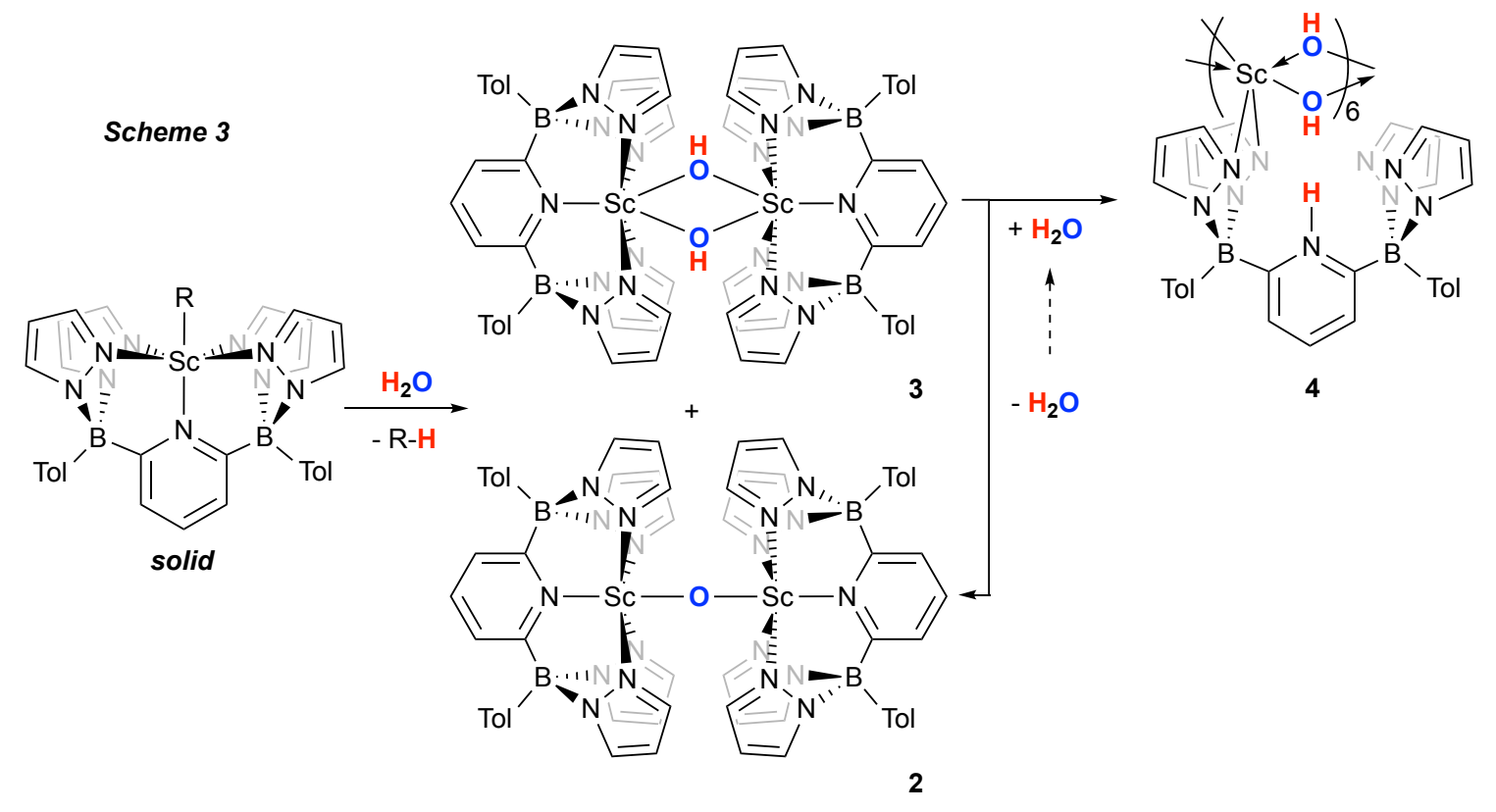

In hexamer 4 , the pentadenticity of the $\mathrm{B}_{2} \mathrm{Pz}_{4} \mathrm{Py}$ ligand is lost upon protonation of the nitrogen on the pyridyl ring; one borate "arm" of the ligand is displaced and the pyrazole rings of this arm are no longer coordinating an Sc center. Each scandium center is coordinated by four bridging hydroxo groups and the two pyrazolyl moieties from the remaining borate arm in a distorted octahedral geometry. The dangling pyrazolyl groups further stabilize the structure through 
hydrogen bonding interactions between either the hydroxyl or pyridinium proton and a pyrazolyl nitrogen as demonstrated by the short contact distances of 2.028(2) and 2.002(3) $\AA$ between $\mathrm{H} 1{ }^{\prime} \cdots \mathrm{N} 7$ and $\mathrm{H} 1 \mathrm{~A} \cdots \mathrm{N} 9$ respectively. The question as to whether this is the only cluster species produced was not probed further; addition of excess or stoichiometric water to the samples of $\mathbf{2}$ and $\mathbf{3}$ generated as described above led to complex mixtures that suggest this hexamer is one species on the road to complete hydrolysis and this issue was not pursued further.

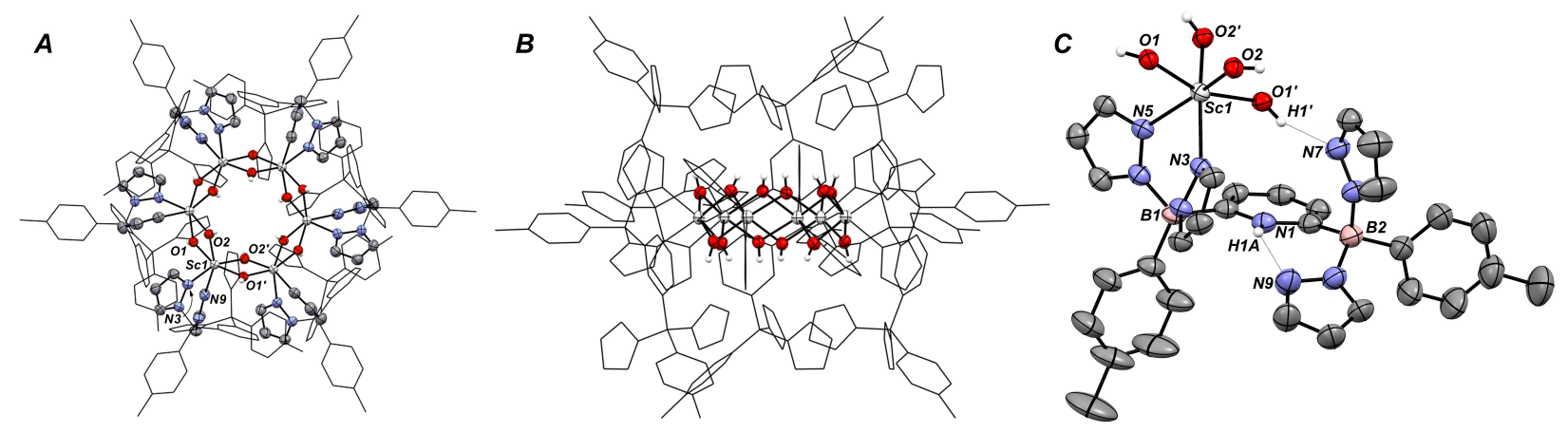

Figure 4. Top-down (A), side view (B) and asymmetric unit (C) of the molecular structure of 4. Hydroxyl groups from the adjacent unit (labelled with a prime symbol) are added to show hydrogen bonding interaction. Most hydrogen atoms have been omitted for clarity. Thermal ellipsoids are shown at the $50 \%$ probability level. Selected bond lengths $(\AA)$ and angles $\left(^{\circ}\right)$ : Sc1-

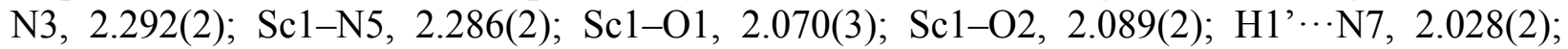
H1A $\cdots \mathrm{N} 9,2.002(3)$; O1-Sc1-O2, 72.86(7); Sc1-O1-Sc1', 107.81(7); Sc1-O2-Sc1', 106.19(7).

The above observations suggest that the Sc-O-Sc oxo bridged dimer 2 and hydroxo bridged complex 3 can be converted into each other with addition of elimination of water. Indeed, treatment of 2 with $\mathrm{H}_{2} \mathrm{O}$ (close to one equivalent- the scale of the reactions made accurate addition of exactly one equivalent of water challenging) led to mixtures of 2,3 and further hydrolysis products (such as 4). Density functional theory computations on the conversion of $\mathbf{3}$ to $\mathbf{2}$ with loss of $\mathrm{H}_{2} \mathrm{O}$ reveals that this process is moderately endothermic, (by $13.2 \mathrm{kcal} \mathrm{mol}^{-1}$, Figure 5) but that the barrier to water loss is rather low. The fact that the 
eliminated water reacts further with $\mathbf{3}$ at rates competitive with the reverse reaction renders the hydroxo complex kinetically unstable, despite its greater thermodynamic stability. Although the water adduct of $\mathbf{2}$ (labeled as I in Figure 5) is computed to be relatively stable, these species are likely in rapid equilibrium and so it was not spectroscopically observable.

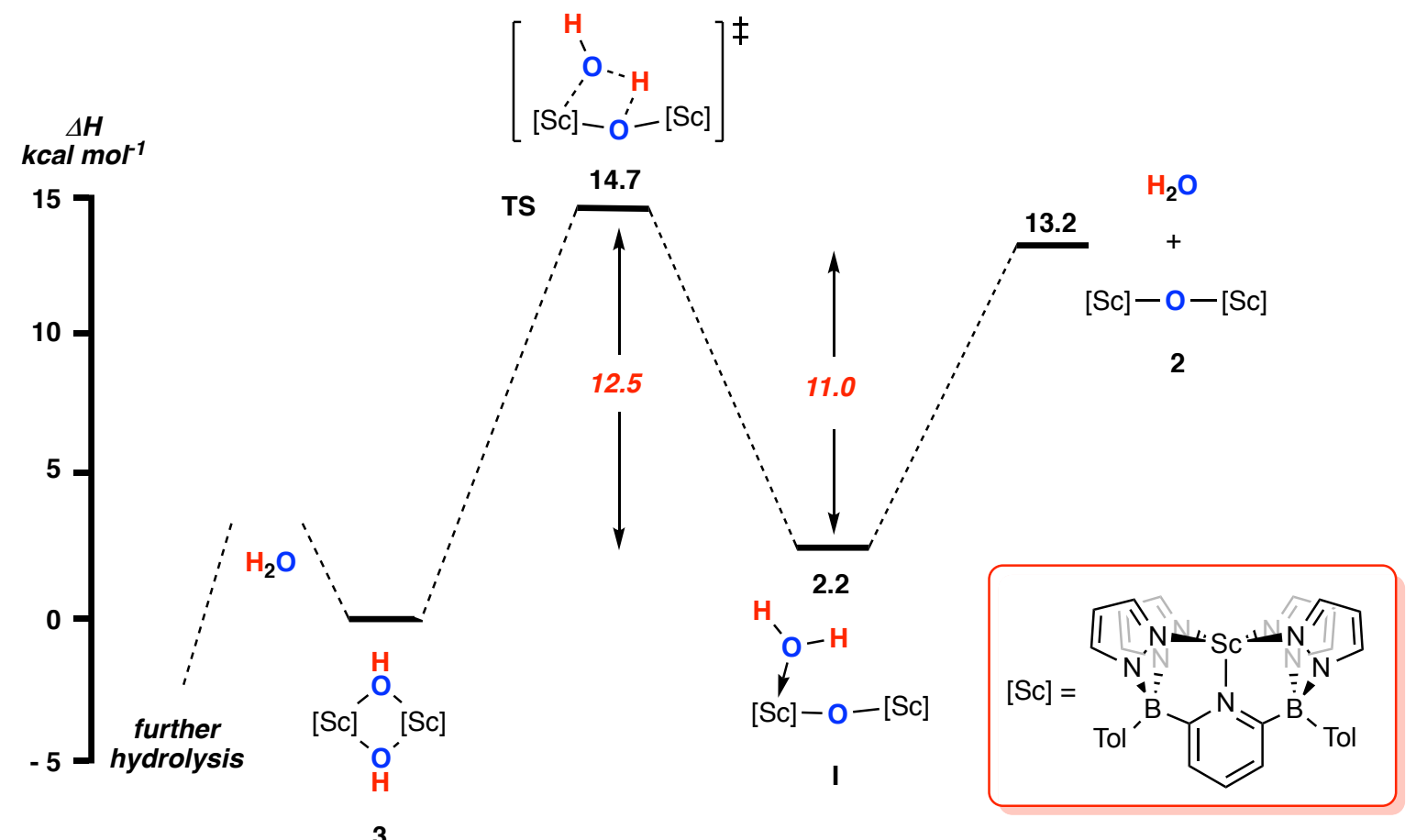

Figure 5. Computed reaction profile (DFT, B3PW91) for conversion of $\mathbf{3}$ into $\mathbf{2}$ and $\mathrm{H}_{2} \mathrm{O}$.

Since hydroxo dimer 3 was not obtainable in pure form via reaction of $\mathbf{1}-\mathrm{CH}_{2} \mathrm{SiMe}_{3}$ with water, partly due to its reactivity towards water, other methods that did not involve addition of water to prepare it were explored. We envisioned that one equivalent of the stronger triflimidic acid $\mathrm{HNTf}_{2}$ would protonate the $\mu$-oxo ligand and generate " $\left(\mathrm{B}_{2} \mathrm{Pz}_{4} \mathrm{Py}\right) \mathrm{ScOH}$ " and the salt 1NTf $_{2}$. This reaction does cleanly generate the latter compound (Scheme 4), which can also be 


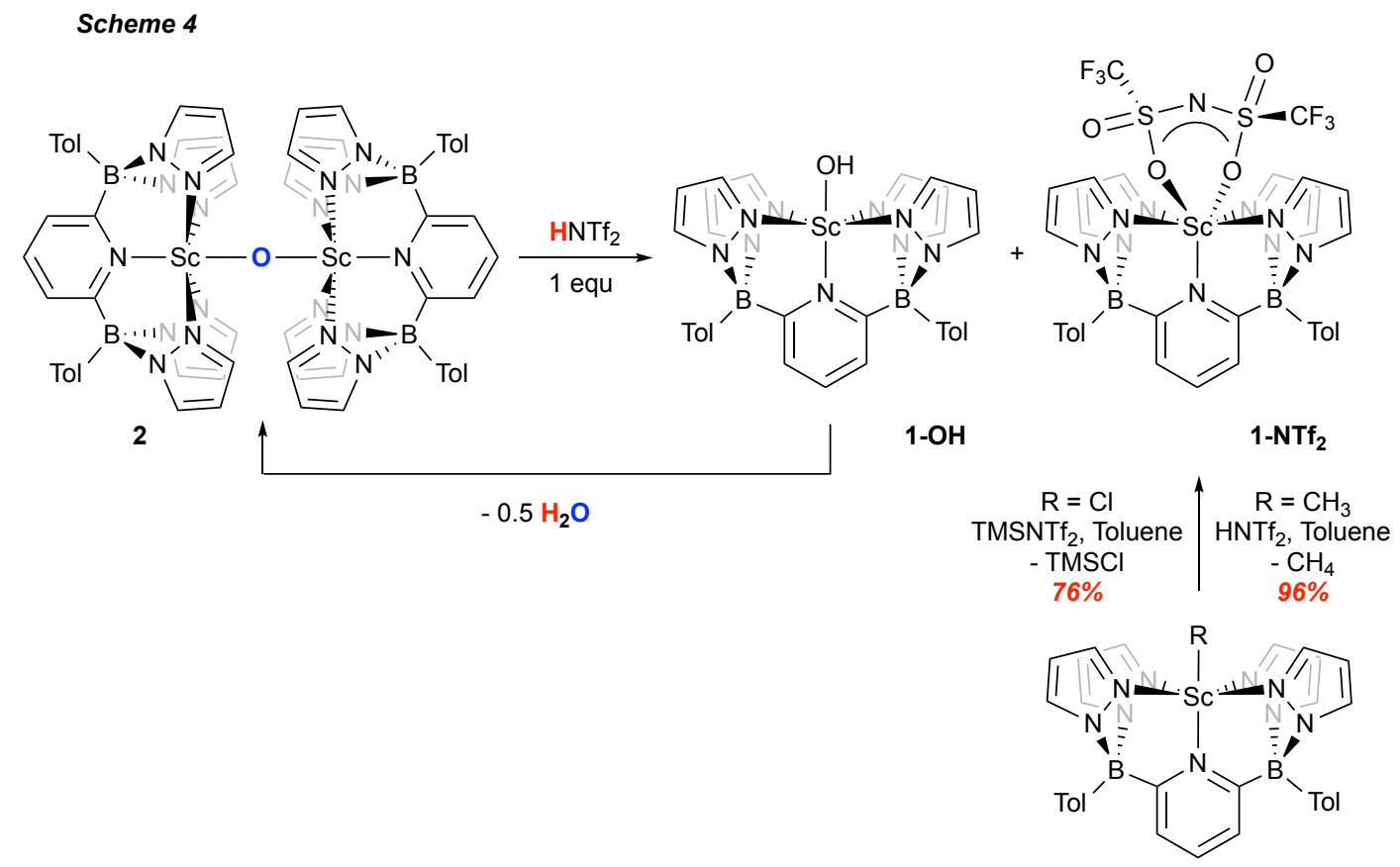

synthesized separately through reaction of $\mathbf{1 - C l}$ with $\mathrm{TMSNTf}_{2}$ (76\% yield) or by protonation of 1-CH $\mathbf{C H}_{3}$ with $\mathrm{HNTf}_{2}$ (96\% yield). The ${ }^{19} \mathrm{~F}\left\{{ }^{1} \mathrm{H}\right\}$ NMR spectrum of 1-NTf $\mathbf{f}_{\mathbf{2}}$ features a sharp singlet at $-79.2 \mathrm{ppm}$ which indicates equivalent $\mathrm{CF}_{3}$ groups. Poor quality crystals allowed for

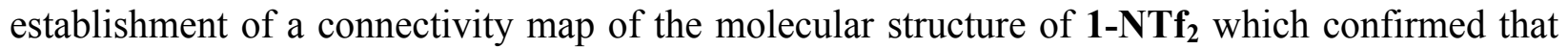
the $\mathrm{NTf}_{2}$ counteranion coordinates to the $\mathrm{Sc}(\mathrm{III})$ center through two of the sulfonyl oxygen atoms in a $\kappa^{2}(\mathrm{O}, \mathrm{O})$ fashion (Figure S4). Despite the clean production of $\mathbf{1 - N T \mathbf { N } _ { 2 }}$ in this reaction, the spectroscopic signature of the hydroxo dimer $\mathbf{3}$ was not observed under these conditions, and instead only oxo dimer $\mathbf{2}$ is observed in the product mixture. We speculate that the monomer of $\mathbf{3}$ (i.e. 1-OH) more favourably condenses back to 2 with elimination of water than it dimerizes to 3, although we are unable to detect the presumed eliminated water directly. However, addition of two equivalents of $\mathrm{HNTf}_{2}$ to $\mathbf{2}$ results in complete conversion to 1-NTf $\mathbf{N}_{2}$, which undergoes slow degradation through reaction with eliminated water. Indeed, crystals grown from these samples consist of the hydroxo dimer $\mathbf{5}$ shown in Scheme 5; this compound is (formally) the product of 
the reaction of $\mathbf{1 - N T \mathbf { f } _ { 2 }}$ with water, through protonation of the pyridyl nitrogen of the $\mathrm{B}_{2} \mathrm{Pz}_{4} \mathrm{Py}$ ligand and addition of an $\mathrm{OH}$ group to the scandium center.

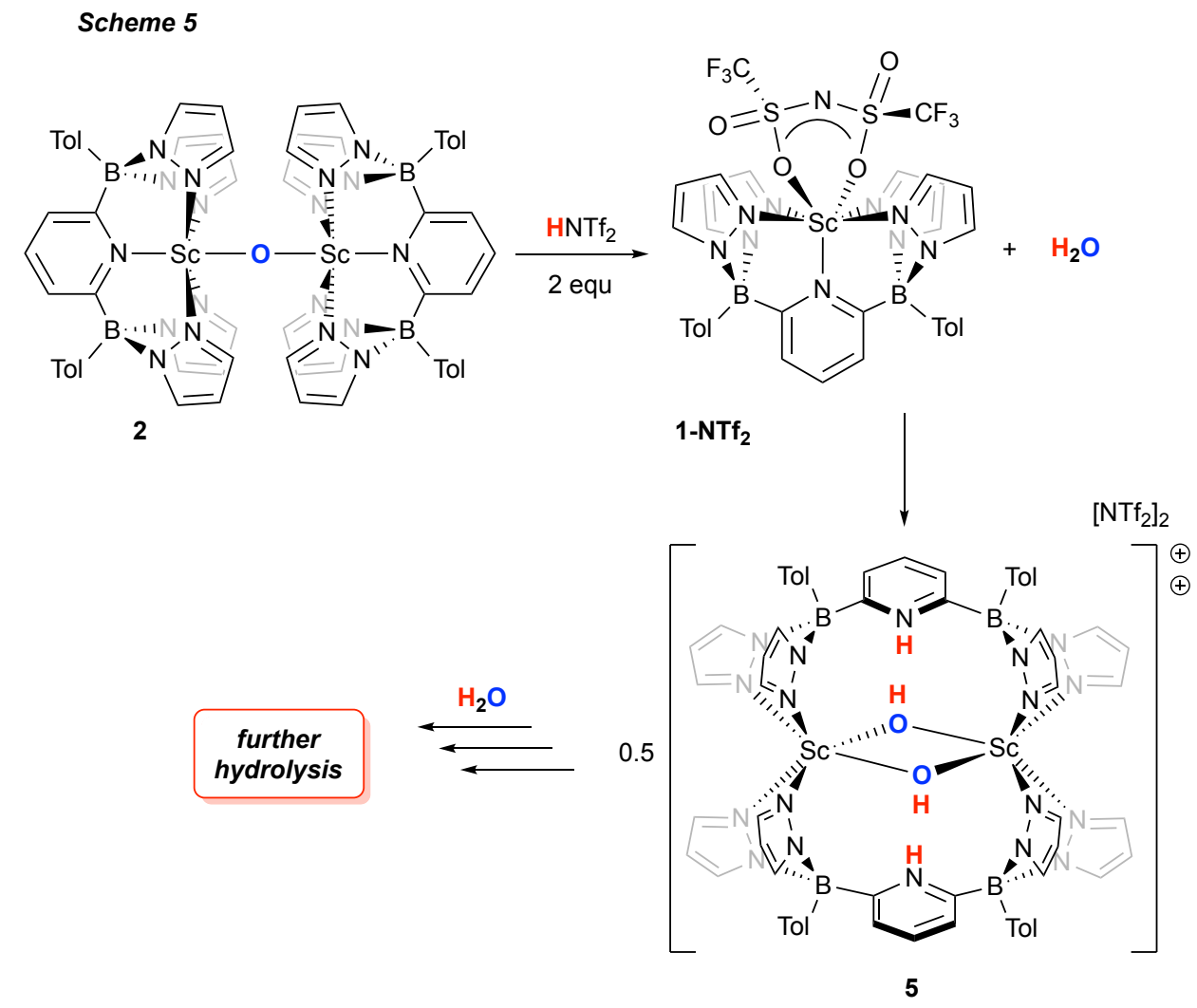

The molecular structure of $\mathbf{5}$, determined by X-ray crystallography, reveals a dicationic dimeric scandium hydroxo complex with $\mathrm{NTf}_{2}$ counteranions (Figure 6). The scandium atoms adopt a slightly distorted octahedral geometry in which the pyrazolyl nitrogens from opposing units coordinate to it. The Sc-O bond lengths of 2.052(3) and 2.064(3) $\AA$ are consistent with other scandium $\mu-\mathrm{OH}$ dimers. Compound 5 also has a $\mathrm{H} 1{ }^{\cdots} \mathrm{O} 1 \mathrm{~A}^{\prime}$ distance of 2.045(5) $\AA$ between the hydroxo and $\mathrm{NTf}_{2}$ anion which is characteristic of hydrogen bonding. Furthermore, a broad $\mathrm{O}-\mathrm{H}$ stretch and sharp $\mathrm{N}-\mathrm{H}$ stretch for the pyridinium proton were observed at 3590 and $3329 \mathrm{~cm}^{-1}$ respectively in the IR spectrum (Figure S5). The ${ }^{1} \mathrm{H}$ NMR spectrum of 5 was not obtainable in benzene solvent, and the reaction mixture only showed a decrease in peak 
intensities of 1-NTf $\mathbf{f}_{2}$ relative to the residual solvent peak of $\mathrm{C}_{6} \mathrm{D}_{6}$ due to precipitation of $\mathbf{5}$ over several days. Attempts to synthesize $\mathbf{5}$ on a preparative scale through the addition of degassed water to $\mathbf{1 - N T f _ { 2 }}$ gave spectra consistent with formation of an aquo intermediate (Figure S6) but the difficulty in controlling stoichiometry precluded isolation of $\mathbf{5}$ due to further hydrolytic reactions.
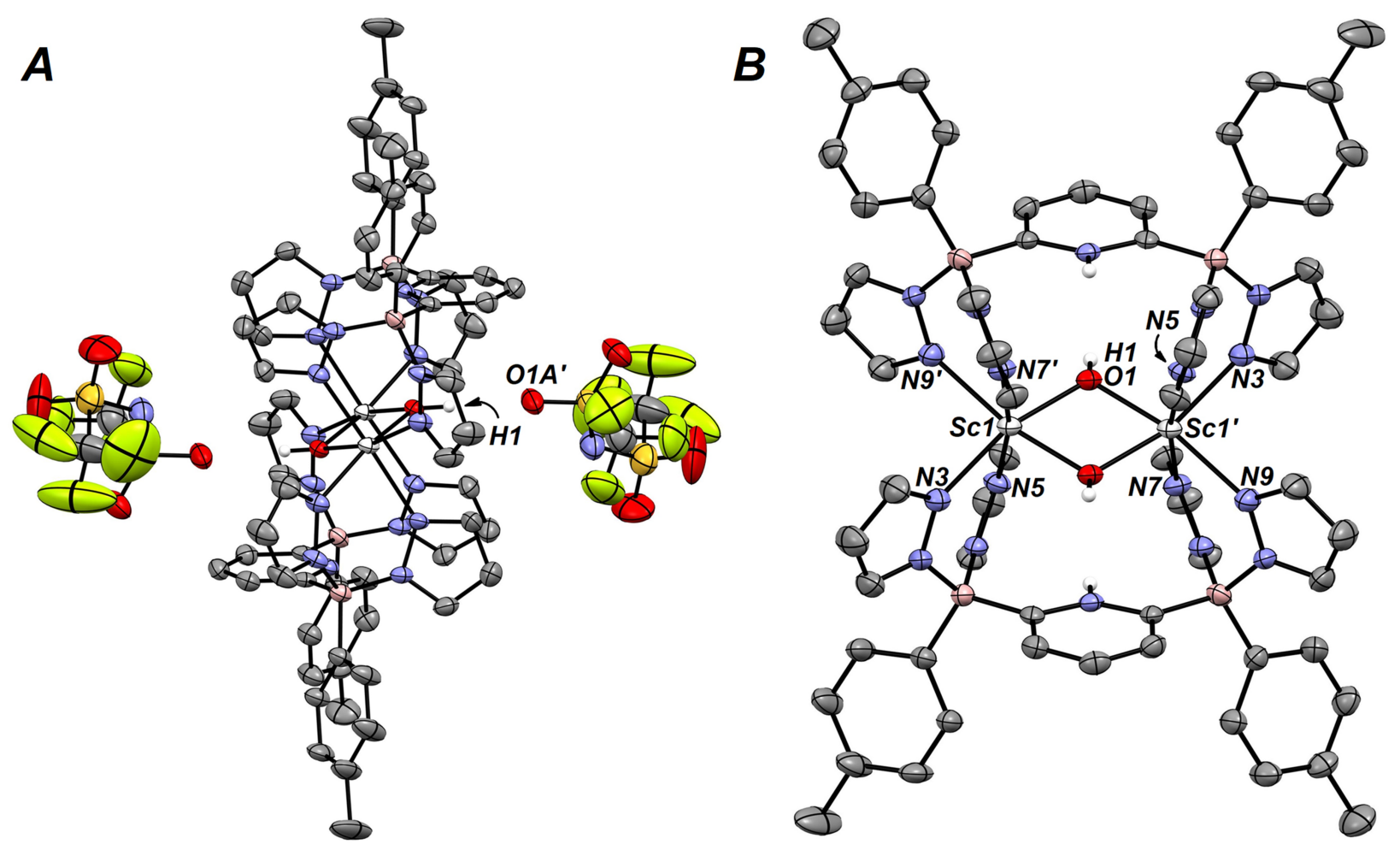

Figure 6. Side (A) and front (B) view of the molecular structure of 5. Triflimide anions in B and most hydrogen atoms have been omitted for clarity. Thermal ellipsoids are shown at the $50 \%$ probability level. Selected bond lengths $(\AA)$ and angles $\left(^{\circ}\right)$ : Sc1-N3, 2.215(5); Sc1-N5, 2.231(4); Sc1-N7', 2.248(4); Sc1-N9', 2.234(4); Sc1-O1, 2.052(3); Sc1-O1', 2.064(3); H1 '.O1A', 2.045(5); O1-Sc1-O2, 75.85(15); Sc1-O1-Sc1', 104.15(15).

\section{Conclusions}

Hydrolysis of the scandium alkyl complex 1- $\mathbf{C H}_{2} \mathbf{S i M e}_{3}$ was examined. Initially, it was assumed that the $\mu$-oxo complex 2 was the thermodynamic product of these reactions,[9] but the system is 
somewhat more complicated. When solid samples of the alkyl are exposed to ambient atmosphere, reproducible mixtures of $\mathbf{2}$ and a new dimeric scandium hydroxo complex $\mathbf{3}$ are produced. This compound eventually converts to $\mathbf{2}$ and other hydrolysis products. DFT computations probed this conversion and it was found that the conversion of $\mathbf{3}$ to $\mathbf{2}$ is endothermic by $13.2 \mathrm{kcal} \mathrm{mol}^{-1}$ but with a low barrier of only $14.7 \mathrm{kcal} \mathrm{mol}^{-1}$. Since other hydrolysis products are observed, it is postulated that the conversion of $\mathbf{3}$ to $\mathbf{2}$ is driven by the reaction of eliminated water with $\mathbf{3}$ to give these products, exemplified by the isolated hexameric dihydroxo complex 4 . Indeed, reaction of $\mu$-oxo dimer 2 with water leads to this and other products (probably via $\mathbf{3}$ ), eventually giving complete hydrolysis. Other routes to the hydroxo dimer $\mathbf{3}$ (or its monomer 1-OH) by reaction of cationic derivative 1-NTf $\mathbf{f}_{2}$ with water were also hampered by subsequent hydrolytic pathways. Nonetheless, this study provides some insight into the pathways by which scandium hydroxos and oxos interconvert using a well-defined pentadentate ligand platform.

\section{Experimental}

For general experimental procedures, see the supplementary information document.

\subsection{Synthesis of 3}

A 1 dram vial charged with solid 1- $\mathrm{CH}_{2} \mathrm{SiMe}_{3}(6 \mathrm{mg})$ was brought out of the box, uncapped and exposed to air for 10 minutes before it was brought back into the box. $\mathrm{C}_{6} \mathrm{D}_{6}$ was added into the vial to dissolve the solid and subsequently transferred into a J Young NMR tube.

${ }^{1} \mathrm{H}$ NMR (500 MHz, $\left.\mathrm{C}_{6} \mathrm{D}_{6}\right) \delta 7.89\left(\mathrm{~d},{ }^{3} J_{\mathrm{HH}}=7.7 \mathrm{~Hz}, 4 \mathrm{H}, p\right.$-Tol Ar), $7.69\left(\mathrm{~d},{ }^{3} J_{\mathrm{HH}}=2.2 \mathrm{~Hz}, 4 \mathrm{H}, \mathrm{Pz}\right), 7.55$ -7.51 (m, 6H, Py and Pz), 7.22 (d, ${ }^{3} J_{\mathrm{HH}}=7.8 \mathrm{~Hz}, 4 \mathrm{H}, p$-Tol Ar), 6.79 (t, $\left.{ }^{3} J_{\mathrm{HH}}=7.7 \mathrm{~Hz}, 1 \mathrm{H}, \mathrm{Py}\right), 5.73$ (t, $\left.{ }^{3} J_{\mathrm{HH}}=2.2 \mathrm{~Hz}, 4 \mathrm{H}, \mathrm{Pz}\right), 5.47(\mathrm{~s}, 1 \mathrm{H}, \mathrm{ScO} H), 2.32\left(\mathrm{~s}, 6 \mathrm{H}, p-\mathrm{Tol} \mathrm{C} H_{3}\right) \cdot v_{\mathrm{O}-\mathrm{H}}: 3716 \mathrm{~cm}^{-1}$. 


\subsection{Synthesis of 1-NTf}

A $20 \mathrm{~mL}$ scintillation vial was charged with 1-Cl $(66 \mathrm{mg}, 0.105 \mathrm{mmol})$ and $5 \mathrm{~mL}$ of toluene was added. TMSNTf $_{2}$ (37 mg, $0.105 \mathrm{mmol}, 1.00$ equiv.) was weighed separately in a 1 dram vial and dissolved in 2 $\mathrm{mL}$ of toluene. The solution of $\mathrm{TMSNTf}_{2}$ was added dropwise into a stirred solution of the chloro complex. The reaction mixture was left to stir for one hour at room temperature during which the white suspension turned clear with some oily residue on the sides of the vial. The reaction mixture was filtered through a $0.1 \mu \mathrm{m}$ PTFE syringe filter and the filtrate was transferred into a $50 \mathrm{~mL}$ thick-walled glass vessel equipped with a Kontes PTFE valve plug and subsequently evaporated in vacuo to yield a colourless residue. The residue was triturated and sonicated with $20 \mathrm{~mL}$ of pentane. The white suspension was then filtered through a medium porosity frit and washed with $2 \times 3 \mathrm{~mL}$ of pentane. The product was isolated as a white solid and dried in vacuo $(70 \mathrm{mg}, 0.080 \mathrm{mmol}, 76 \%)$. Single crystals suitable for X-ray diffraction were obtained by slow vapour diffusion of pentane onto a concentrated solution of 1-NTf $\mathbf{f}_{2}$ in toluene at $-35^{\circ} \mathrm{C}$.

${ }^{1} \mathrm{H}$ NMR (500 MHz, $\left.\mathrm{C}_{6} \mathrm{D}_{6}\right) \delta 8.25\left(\mathrm{~d},{ }^{3} J_{\mathrm{HH}}=2.3 \mathrm{~Hz}, 4 \mathrm{H}, \mathrm{Pz}\right), 7.58\left(\mathrm{~d},{ }^{3} J_{\mathrm{HH}}=7.8 \mathrm{~Hz}, 4 \mathrm{H}, p\right.$-Tol Ar), 7.37 $\left(\mathrm{d},{ }^{3} J_{\mathrm{HH}}=2.3 \mathrm{~Hz}, 4 \mathrm{H}, \mathrm{Pz}\right), 7.29\left(\mathrm{~d},{ }^{3} J_{\mathrm{HH}}=7.8 \mathrm{~Hz}, 2 \mathrm{H}, \mathrm{Py}\right), 7.17\left(\mathrm{~d},{ }^{3} J_{\mathrm{HH}}=8.5 \mathrm{~Hz}, 4 \mathrm{H}, p-\mathrm{Tol}\right.$ Ar), 6.64 $\left(\mathrm{t},{ }^{3} J_{\mathrm{HH}}=7.8 \mathrm{~Hz}, 1 \mathrm{H}, \mathrm{Py}\right), 5.75\left(\mathrm{t},{ }^{3} J_{\mathrm{HH}}=2.3 \mathrm{~Hz}, 4 \mathrm{H}, \mathrm{Pz}\right), 2.31(\mathrm{~s}, 6 \mathrm{H}, p-\mathrm{Tol} \mathrm{CH}) .{ }^{13} \mathrm{C}\left\{{ }^{1} \mathrm{H}\right\} \mathrm{NMR}(126$ $\left.\mathrm{MHz}, \mathrm{C}_{6} \mathrm{D}_{6}\right) \delta 171.67(\mathrm{Py}), 141.93(\mathrm{Pz}), 139.43$ (p-Tol Ar), 137.25 (overlapping, p-Tol Ar and Pz), 135.83 (p-Tol Ar), 135.72 (Py), 129.15 (p-Tol Ar), 128.1 (Py), $120.0\left(\mathrm{q},{ }^{1} J_{\mathrm{CF}}=320 \mathrm{~Hz}, C \mathrm{~F}_{3}\right), 105.22$ $(\mathrm{Pz}), 21.35\left(p\right.$-Tol $\left.C \mathrm{H}_{3}\right) .{ }^{11} \mathrm{~B}$ NMR $\left(161 \mathrm{MHz}, \mathrm{C}_{6} \mathrm{D}_{6}\right) \delta 0.08 .{ }^{19} \mathrm{~F}\left\{{ }^{1} \mathrm{H}\right\} \mathrm{NMR}\left(471 \mathrm{MHz}, \mathrm{C}_{6} \mathrm{D}_{6}\right) \delta-79.25$. Elemental Analysis: Calcd. (\%) for $\mathrm{C}_{33} \mathrm{H}_{29} \mathrm{~B}_{2} \mathrm{~F}_{6} \mathrm{~N}_{10} \mathrm{O}_{4} \mathrm{~S}_{2} \mathrm{Sc}$ : C, 45.33; H, 3.34; N, 16.02. Found: C, 45.20; H, 3.32; N, 15.09 .

\subsection{Attempted Synthesis of 5}




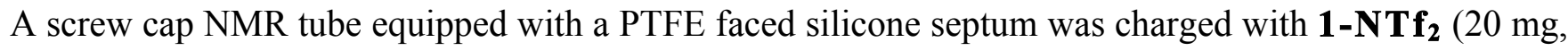
$0.0229 \mathrm{mmol})$ and dissolved in $0.6 \mathrm{~mL}$ of benzene. Degassed water $(0.6 \mu \mathrm{L}, 0.0333 \mathrm{mmol})$ was added by microsyringe through the septum and the mixture was shaken briefly to mix. The colourless solution was left to stand at room temperature overnight and a colourless precipitate formed at the bottom of the NMR tube. Poor solubility precluded acquisition of suitable NMR data but crystals of $\mathbf{5}$ were obtained in

this way. IR: $3590 \mathrm{~cm}^{-1}\left(v_{\mathrm{O}-\mathrm{H}}\right), 3329 \mathrm{~cm}^{-1}\left(v_{\mathrm{N}-\mathrm{H}}\right)$. Elemental Analysis: Calcd. (\%) for $\mathrm{C}_{33} \mathrm{H}_{31} \mathrm{~B}_{2} \mathrm{~F}_{6} \mathrm{~N}_{10} \mathrm{O}_{5} \mathrm{~S}_{2} \mathrm{Sc}: \mathrm{C}, 44.42 ; \mathrm{H}, 3.50 ; \mathrm{N}, 15.70$. Found: $\mathrm{C}, 43.02 ; \mathrm{H}, 3.31 ; \mathrm{N}, 12.43$.

\section{Acknowledgement}

Funding for this work was provided by NSERC of Canada in the form of a Discovery Grant W.E.P. W.E.P also thanks the Canada Research Chair secretariat for a Tier I CRC (2013-2020). L.M. is member of the Institut Universitaire de France. Chinese Science Council (CSC) is acknowledged for financial support (Ph. D. support for Y.Y.). The authors acknowledges the HPCs CALcul en Midi-Pyrénées (CALMIP).

\section{Appendix A. Supplementary data}

Supplementary data containing general experimental details, NMR spectra, connectivity map of 1-NTf $\mathbf{N}_{2}$ and computational details can be found online. Supplementary crystallographic data for 3, 4 and 5 have been uploaded to the Cambridge Crystallographic Data Centre. CCDC numbers are CCDC 1969841-1969843, respectively, and can be accessed free of charge at http://www.ccdc.cam.ac.uk/retrieving.html. 


\subsection{References}

[1] H.W. Roesky, S. Singh, K.K.M. Yusuff, J.A. Maguire, N.S. Hosmane, Organometallic Hydroxides of Transition Elements, Chemical Reviews, 106 (2006) 3813-3843.

[2] J.A. Garden, S.D. Pike, Hydrolysis of organometallic and metal-amide precursors: synthesis routes to oxo-bridged heterometallic complexes, metal-oxo clusters and metal oxide nanoparticles, Dalton Transactions, 47 (2018) 3638-3662.

[3] S.K. Mandal, H.W. Roesky, Assembling Heterometals through Oxygen: An Efficient Way To Design Homogeneous Catalysts, Accounts of Chemical Research, 43 (2010) 248-259.

[4] G.L. Hillhouse, J.E. Bercaw, Reactions of water and ammonia with bis(pentamethylcyclopentadienyl) complexes of zirconium and hafnium, Journal of the American Chemical Society, 106 (1984) 5472-5478.

[5] T. Beweries, V.V. Burlakov, S. Peitz, P. Arndt, W. Baumann, A. Spannenberg, U. Rosenthal, Synthesis and Reactions of $\mathrm{Cp} * 2 \mathrm{Hf}\left(\eta^{2}-\mathrm{PhC}_{2} \mathrm{SiMe}_{3}\right)$ with Water and Carbon Dioxide, Organometallics, 27 (2008) 3954-3959.

[6] M. Horáček, R. Gyepes, J. Kubišta, K. Mach, Synthesis and crystal structure of decamethyltitanocene hydroxide, Inorganic Chemistry Communications, 7 (2004) 155-159.

[7] M. Kessler, S. Hansen, C. Godemann, A. Spannenberg, T. Beweries, Synthesis and Structures of ansa-Titanocene Complexes with Diatomic Bridging Units for Overall Water Splitting, Chemistry - A European Journal, 19 (2013) 6350-6357.

[8] M. Bochmann, A.J. Jaggar, L.M. Wilson, M.B. Hursthouse, M. Motevalli, Synthesis of cationic alkyl bis(cyclopentadienyl)titanium complexes by one-electron oxidation of titanium(III) alkyls. The structure of [Cp2*TiMe(THF)]BPh4 and [Cp2*Ti(OH)(H2O)]BPh4·2THF, Polyhedron, 8 (1989) 1838-1843.

[9] D.W. Beh, W.E. Piers, I. del Rosal, L. Maron, B.S. Gelfand, C. Gendy, J.-B. Lin, Scandium alkyl and hydride complexes supported by a pentadentate diborate ligand: reactions with $\mathrm{CO}_{2}$ and $\mathrm{N}_{2} \mathrm{O}$, Dalton Trans., 47 (2018) 13680-13688.

[10] R. Waterman, $\sigma$-Bond Metathesis: A 30-Year Retrospective, Organometallics, 32 (2013) 7249-7263.

[11] M.E. Thompson, S.M. Baxter, A.R. Bulls, B.J. Burger, M.C. Nolan, B.D. Santarsiero, W.P. Schaefer, J.E. Bercaw, sigma.-Bond metathesis for carbon-hydrogen bonds of hydrocarbons and Sc-R $(\mathrm{R}=\mathrm{H}$, alkyl, aryl) bonds of permethylscandocene derivatives. Evidence for noninvolvement of the pi. system in electrophilic activation of aromatic and vinylic C-H bonds, Journal of the American Chemical Society, 109 (1987) 203-219.

[12] C. Meermann, K.W. Törnroos, R. Anwander, Scandium SALEN Complexes Bearing Chloro, Aryloxo, and Hydroxo Ligands, Inorg. Chem., 48 (2009) 2561-2570. 
[13] R. Staples, Y. Aye, Structural Report for $\mathrm{Sc}[(\mathrm{R}, \mathrm{R})$-norephedrine-pybox $](\mathrm{OTf})_{3}$ Dimeric Complex, J. Chem. Crystallogr., 38 (2007) 49-52.

[14] M.D. Brown, W. Levason, D.C. Murray, M.C. Popham, G. Reid, M. Webster, Primary and secondary coordination of crown ethers to scandium(III). Synthesis, properties and structures of the reaction products of $\mathrm{ScCl}_{3}(\mathrm{thf})_{3}, \mathrm{ScCl}_{3} \cdot 6 \mathrm{H}_{2} \mathrm{O}$ and $\mathrm{Sc}\left(\mathrm{NO}_{3}\right)_{3} \cdot 5 \mathrm{H}_{2} \mathrm{O}$ with crown ethers, Dalton Trans., (2003) 857-865.

[15] A.M. Arif, F.A. Hart, M.B. Hursthouse, M. Thornton-Pett, W. Zhu, The complex chemistry of scandium. Part 1. Preparation and properties of some scandium(III) complexes of polyamines. $\mathrm{X}$-Ray crystal structures of tri(nitrato-OO') $\left(2,2^{\prime}: 6^{\prime}, 2^{\prime \prime}\right.$-terpyridyl-NN'N")scandium(III) and [1,2bis(pyridine- $\alpha$-carbaldimino)ethane-NN'N" $\left.\mathrm{N}^{\prime \prime \prime}\right]$-di- $\mu$-hydroxo-di(nitrato-OO')discandium(III) dinitrate bis(acetonitrile), J. Chem. Soc., Dalton Trans., (1984) 2449-2454.

[16] A.S. de Sousa, M.A. Fernandes, W. Nxumalo, J.L. Balderson, T. Jeftič, I. Cukrowski, H.M. Marques, Sc(III) porphyrins. The molecular structure of two $\mathrm{Sc}(\mathrm{III})$ porphyrins and a reevaluation of the parameters for the molecular mechanics modelling of $\mathrm{Sc}(\mathrm{III})$ porphyrins, J. Mol. Struct., 872 (2008) 47-55.

[17] J. Arnold, C.G. Hoffman, D.Y. Dawson, F.J. Hollander, Preparation, characterization, and reactivity of scandium octaethylporphyrin complexes. X-ray crystal structures of (OEP) $\mathrm{ScCH}_{3}$, $(\mathrm{OEP}) \mathrm{ScCH}\left(\mathrm{SiMe}_{3}\right)_{2},(\mathrm{OEP}) \mathrm{Sc}\left(\eta^{5}-\mathrm{C}_{9} \mathrm{H}_{7}\right)$, and $[(\mathrm{OEP}) \mathrm{Sc}]_{2}(\mu-\mathrm{OH})_{2}$, Organometallics, 12 (1993) $3645-3654$. 


\title{
Supporting Information
}

\section{Hydrolysis of Scandium Alkyl Derivatives Supported by a Pentadentate Diborate Ligand: Interconversion of Hydroxo and Oxo Complexes}

\author{
Daniel W. Beh, ${ }^{\dagger}$ Warren E. Piers, ${ }^{\dagger *}$ Laurent Maron,${ }^{\dagger}$ Yan Yang, ${ }^{\dagger}$ Benjamin S. Gelfand ${ }^{\dagger}$ and Jian- \\ $\operatorname{Bin~} \mathrm{Li}^{\dagger}$ \\ 'Department of Chemistry, University of Calgary, 2500 University Drive NW, \\ Calgary, Alberta, Canada T2N 1N4 \\ LPCNO, Université de Toulouse, INSA, UPS, LPCNO, 135 avenue de Rangueil, F- 31077 \\ Toulouse, France, and CNRS, LPCNO, F-31077 Toulouse, France
}

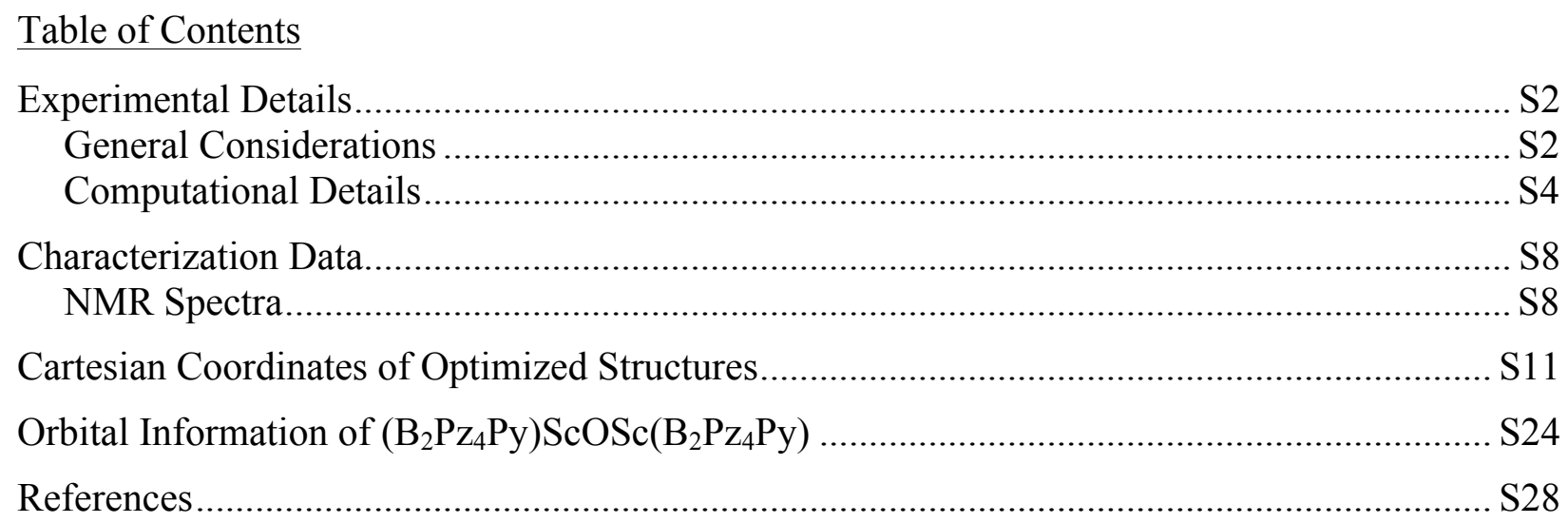




\section{$\underline{\text { Experimental Details }}$}

\section{General Considerations}

Manipulation and storage of all oxygen and moisture sensitive materials was performed under an argon atmosphere in a MBRAUN glove box. Reactions were performed on a double manifold high vacuum line fitted with an OxisorBW scrubber (Matheson Gas products) argon purification cartridge, using standard techniques. Glassware was stored in a $135^{\circ} \mathrm{C}$ oven prior to immediate transfer to the glovebox antechamber or assembly on the vacuum line and evacuated while hot.

Toluene and $n$-pentane were dried and purified using a Grubbs/Down purification system [1], and stored in evacuated $500 \mathrm{~mL}$ thick-walled vessels over sodium/benzophenone ketal. Benzene$d_{6}$ was dried and stored over sodium/benzophenone ketyl. All dried solvents were degassed and vacuum transferred prior to use into thick-walled glass vessels for storage over activated molecular sieves $(4 \AA) . \quad\left(\mathrm{B}_{2} \mathrm{Pz}_{4} \mathrm{Py}\right) \mathrm{ScR} \quad\left(\mathrm{R}=\mathrm{Cl}, \mathrm{CH}_{3}, \mathrm{CH}_{2} \mathrm{SiMe}_{3}\right) \quad[2]$, and $\left(\mathrm{B}_{2} \mathrm{Pz}_{4} \mathrm{Py}\right) \mathrm{ScOSc}\left(\mathrm{B}_{2} \mathrm{Pz}_{4} \mathrm{Py}\right)[2]$ were prepared according to literature procedures. $\mathrm{HNTf}_{2}$ and $\mathrm{TMSNTf}_{2}$ were purchased from Sigma-Aldrich and TCI Chemicals respectively, and were used as received.

Nuclear magnetic resonance spectroscopy experiments including ${ }^{1} \mathrm{H},{ }^{11} \mathrm{~B},{ }^{13} \mathrm{C}\left\{{ }^{1} \mathrm{H}\right\}$, ${ }^{19} \mathrm{~F}\left\{{ }^{1} \mathrm{H}\right\},{ }^{1} \mathrm{H}-{ }^{1} \mathrm{H}$ COSY,${ }^{1} \mathrm{H}-{ }^{13} \mathrm{C}$ HMBC, ${ }^{1} \mathrm{H}-{ }^{13} \mathrm{C}$ HSQC and ${ }^{1} \mathrm{H}-{ }^{1} \mathrm{H}$ NOESY were performed on Ascend-500 or Avance-600 spectrometers. For DOSY experiment, the gradient amplitude was varied from $2 \%$ to $95 \%$ with an optimized $\delta$ (gradient pulse length) of $2600 \mu$ s and a $\Delta$ (diffusion time) of 0.075 s. All ${ }^{1} \mathrm{H}$ and ${ }^{13} \mathrm{C}\left\{{ }^{1} \mathrm{H}\right\}$ NMR spectra were internally referenced relative to $\mathrm{Si}\left(\mathrm{CH}_{3}\right)_{4}$ using residual solvent protons and naturally abundant ${ }^{13} \mathrm{C}$ resonances for all deuterated 
solvents [3]. NMR spectra were processed and analyzed with MestReNova (v. 9.0.1-13254). NMR spectra are presented with the following format: chemical shift (ppm) (multiplicity, ${ }^{\mathrm{n}} J_{\mathrm{XY}}=$ coupling constant (Hz), integration, assignment). ${ }^{11} \mathrm{~B},{ }^{13} \mathrm{C}\left\{{ }^{1} \mathrm{H}\right\}$ and ${ }^{19} \mathrm{~F}\left\{{ }^{1} \mathrm{H}\right\}$ spectra have integration omitted from the reported format.

X-ray crystallographic analyses for all other compounds were performed by Drs. Benjamin Gelfand and Jian-Bin Li on either a Nonius Kappa CCD diffractometer using graphitemonochromated Mo K $\alpha$ radiation or a Bruker Smart APEX II three-circle diffractometer using $\mathrm{Cu} \mathrm{K} \alpha$ radiation. Crystals were coated in Fomblin Y HVAC 140/13 oil. More details on individual structures can be found in on 


\section{Table S1.}

Elemental analyses were performed by Johnson Li using a Perkin Elmer Model 2400 Series II analyser at the Instrumentation Facility of the Department of Chemistry, University of Calgary.

\section{Computational Details}

All DFT calculations were carried out with the Gaussian 09 suite of programs [4]. Geometries were fully optimized in gas phase without symmetry constraints, employing the B3PW91 functional [5]. The nature of the extrema was verified by analytical frequency calculations. The calculation of electronic energies and enthalpies of the extrema of the potential energy surface (minima and transition states) were performed at the same level of theory as the geometry optimizations. IRC calculations were performed to confirm the connections of the optimized transition states. Scandium atoms were treated with Stuttgart effective core potential and their associated basis set [6]. For the other elements (H, C, O, N and B), Pople's double- $\zeta$ basis set 6-31G(d,p) was used [7]. 


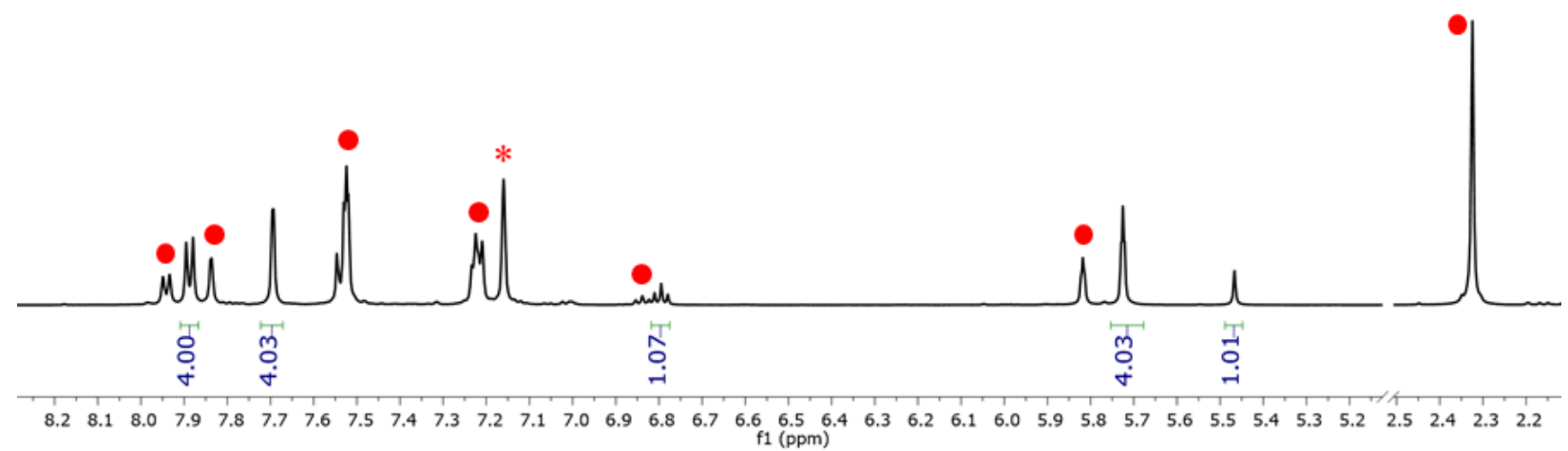

Figure S1 ${ }^{1} \mathrm{H}$ NMR spectrum of the resulting solid in $\mathrm{C}_{6} \mathrm{D}_{6}$ after exposing $\left(\mathrm{B}_{2} \mathrm{Pz}_{4} \mathrm{Py}\right) \mathrm{ScCH}_{2} \mathrm{SiMe}_{3}$ briefly to air, with red dots corresponding to 2 . Only certain nonoverlapping ligand resonances for $\mathbf{1}$ have been integrated. Solvent residual signal indicated with an asterisk.

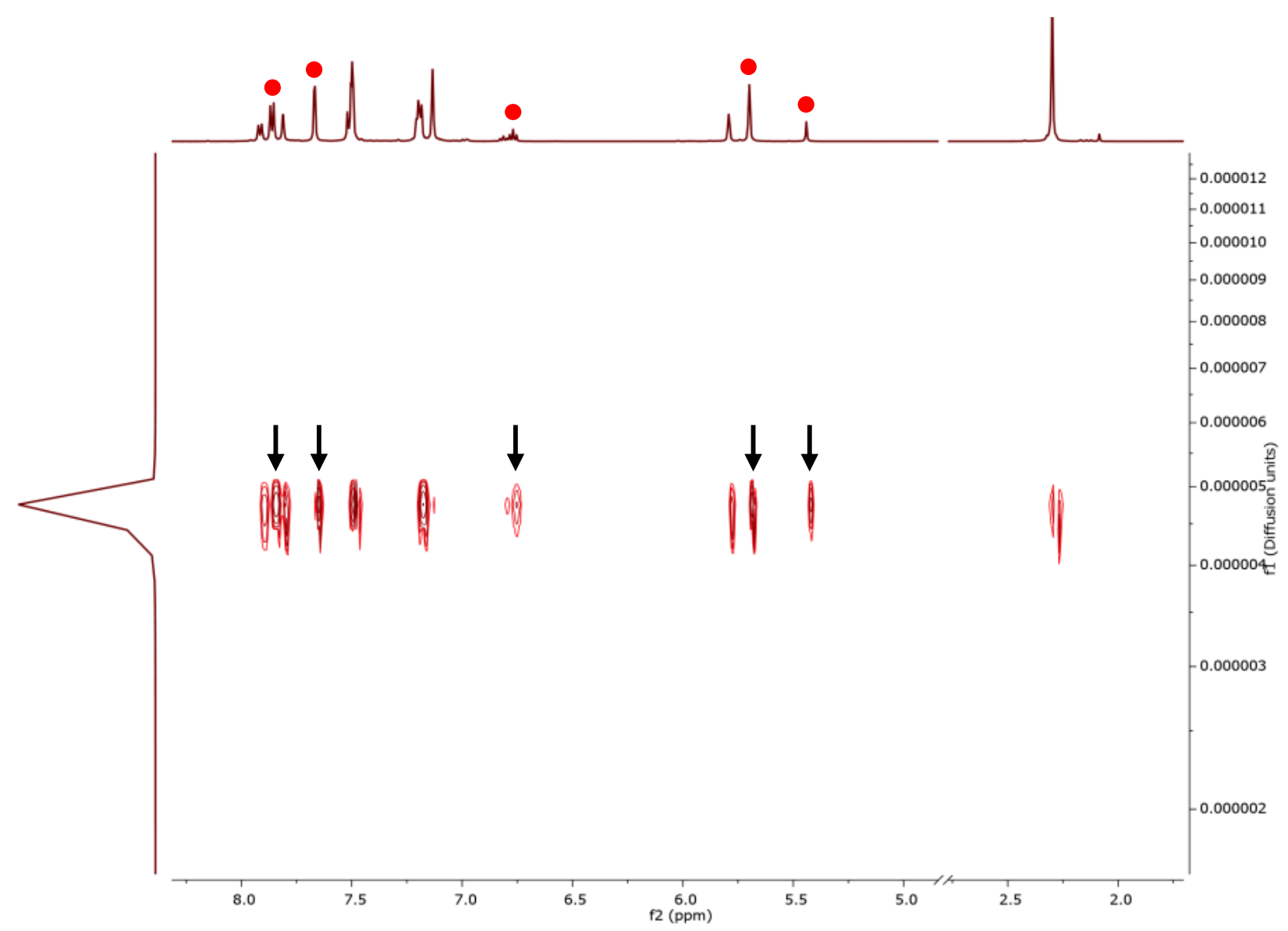

Figure S2 DOSY spectrum of the mixture of $\mathbf{2}$ and $\mathbf{3}$ in $\mathrm{C}_{6} \mathrm{D}_{6}$. Some cross peaks corresponding to $\mathbf{3}$ are indicated with arrows and red dots. 


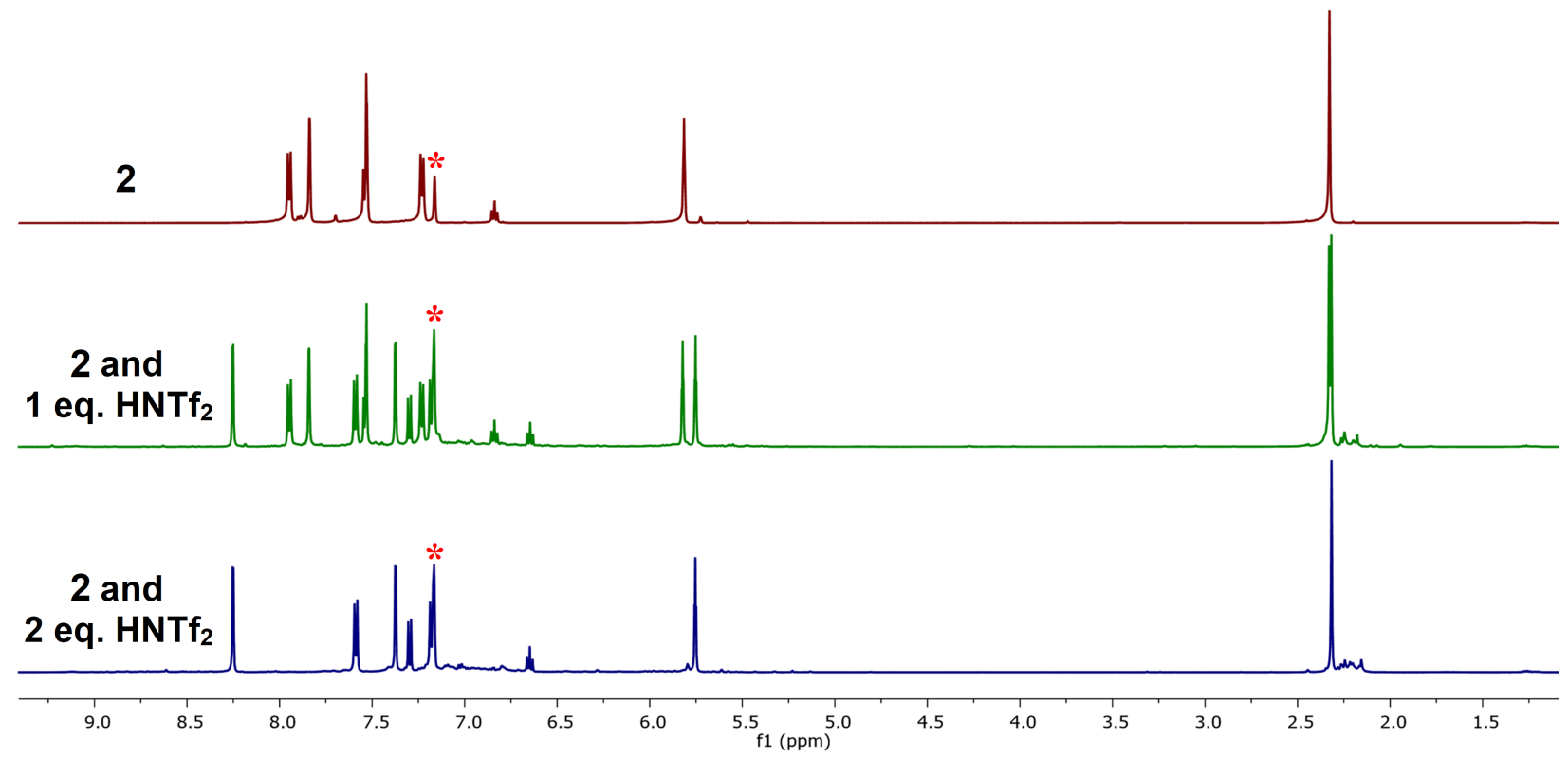

Figure S3 ${ }^{1} \mathrm{H}$ NMR spectra in $\mathrm{C}_{6} \mathrm{D}_{6}$ of the addition of 1 (middle) and 2 (bottom) equivalents of $\mathrm{HNTf}_{2}$ to 2. Complete formation of $\mathbf{1 - N T f _ { 2 }}$ with excess $\mathrm{HNTf}_{2}$. Solvent residual signal indicated with an asterisk.

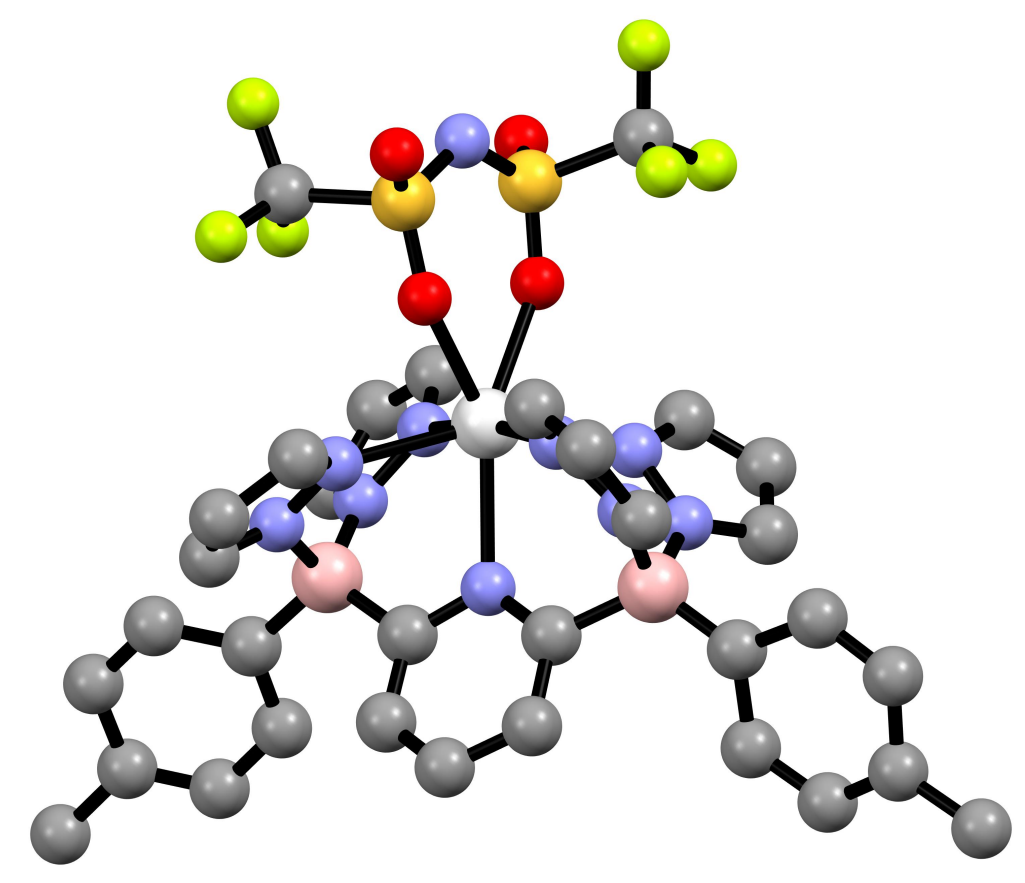

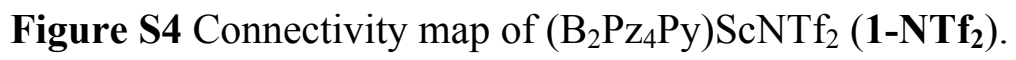




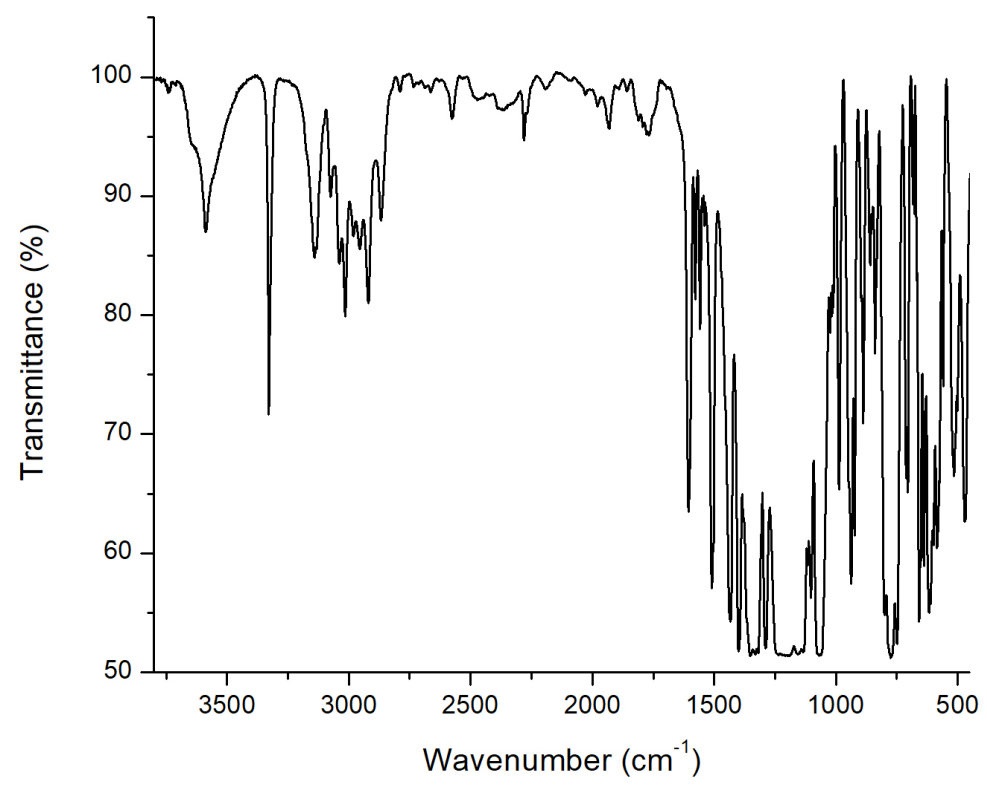

Figure S5 FT-IR spectrum of 5 showing prominent $\mathrm{O}-\mathrm{H}$ and $\mathrm{N}-\mathrm{H}$ bond stretches at 3590 and $3329 \mathrm{~cm}^{-1}$ respectively.
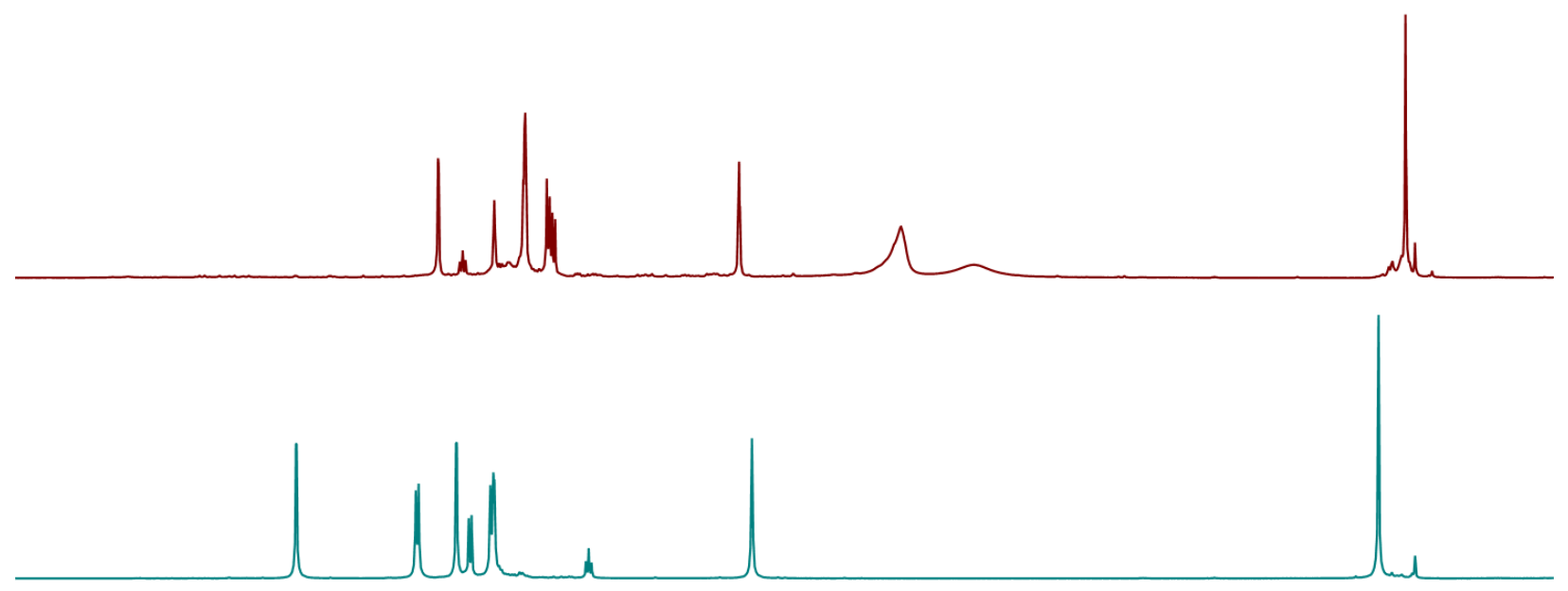

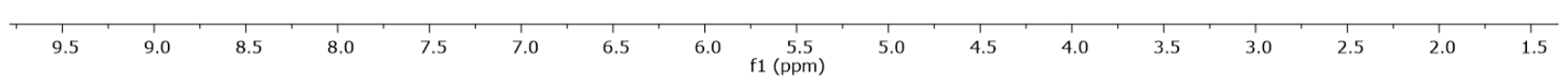

Figure S6 Stacked ${ }^{1} \mathrm{H}$ NMR spectra to indicate differences in chemical shifts of ligand resonances before (bottom) and after (top) addition of water to $\mathbf{1 - N T f _ { 2 }}$ in $\mathrm{C}_{6} \mathrm{D}_{6}$. 


\section{Characterization Data}

NMR Spectra

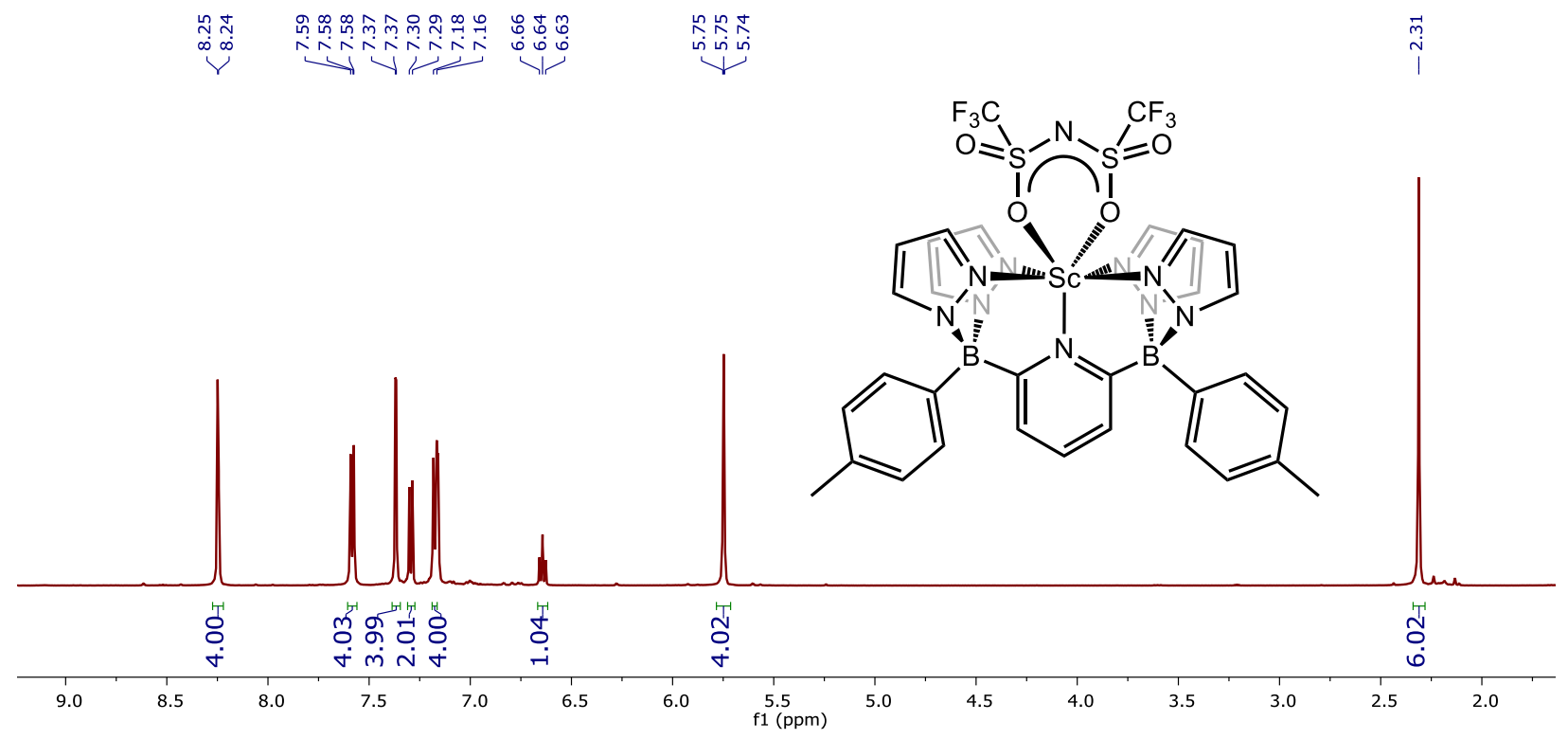

Figure $\mathbf{S 7}{ }^{1} \mathrm{H}$ NMR spectrum of $\mathbf{1 - N T f _ { 2 }}$ in $\mathrm{C}_{6} \mathrm{D}_{6}$.

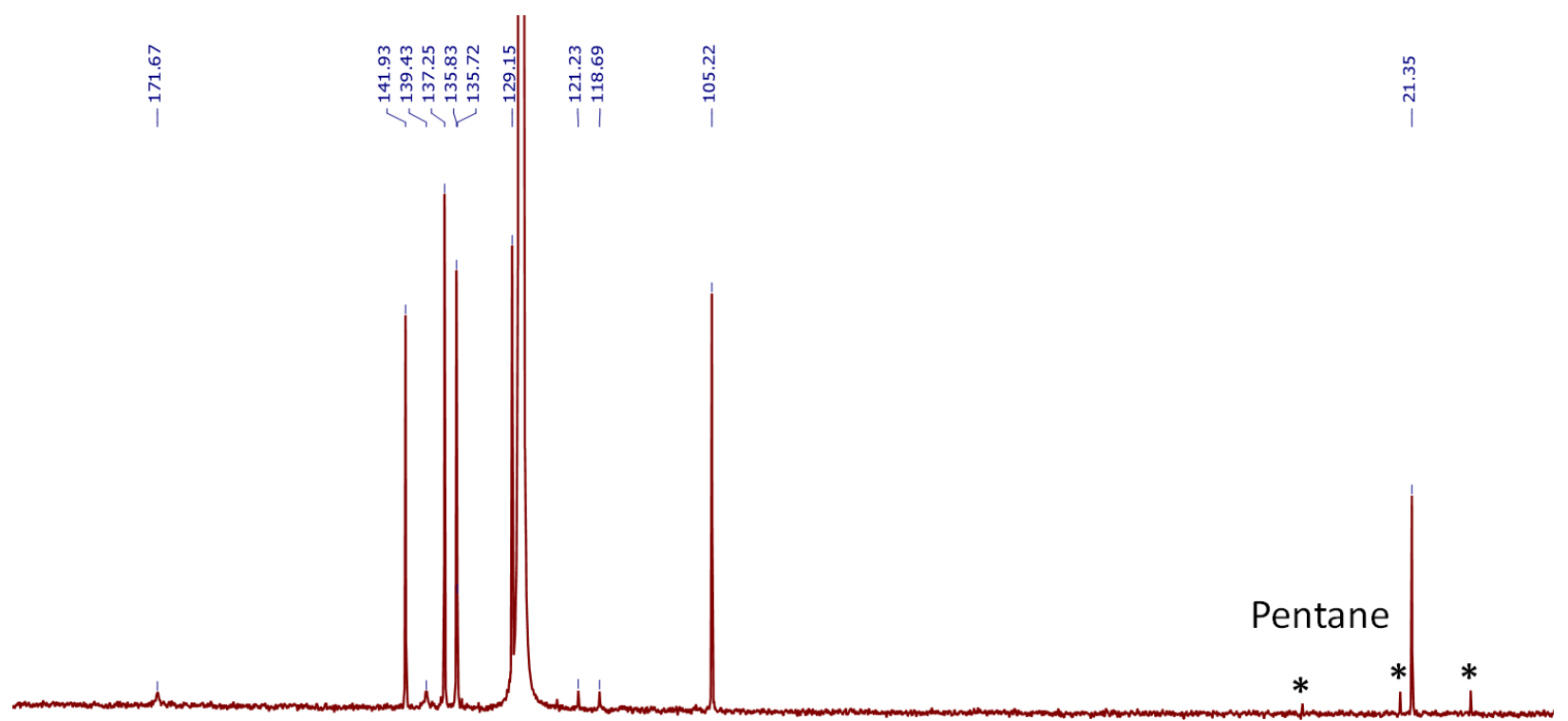

Figure S8 ${ }^{1} \mathrm{H}$ NMR spectrum of $\mathbf{1 - N T \mathbf { f } _ { 2 }}$ in $\mathrm{C}_{6} \mathrm{D}_{6}$. 


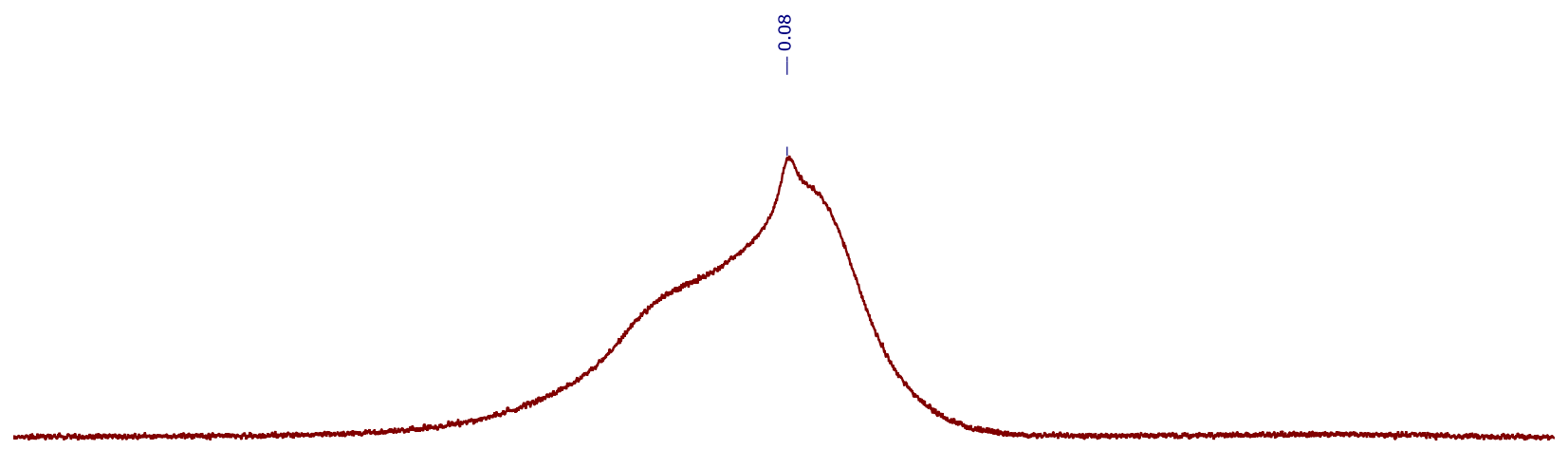

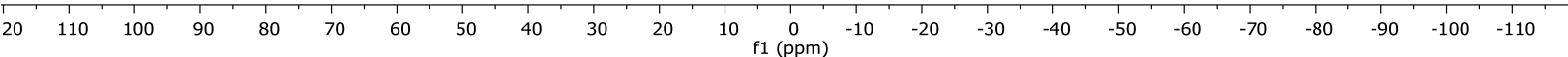

Figure S9 ${ }^{11} \mathrm{~B}$ NMR spectrum of $\mathbf{1 - N T f _ { 2 }}$ in $\mathrm{C}_{6} \mathrm{D}_{6}$.

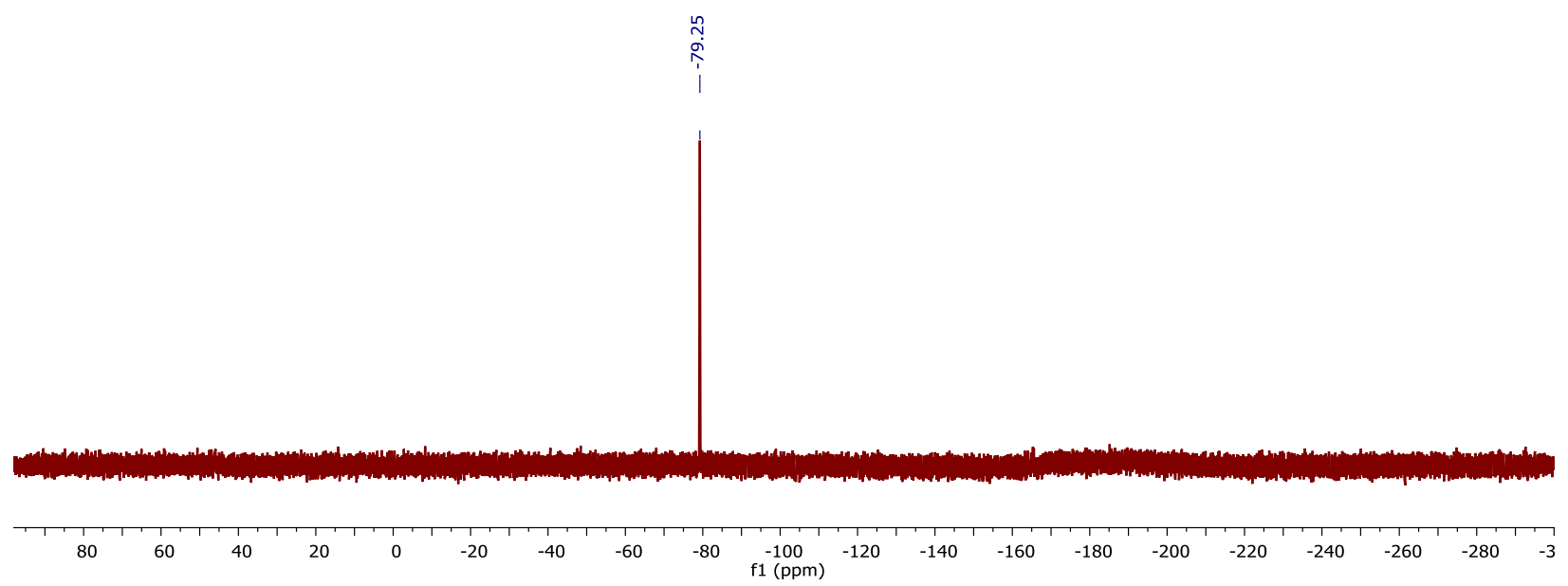

Figure S10 ${ }^{19} \mathrm{~F}\left\{{ }^{1} \mathrm{H}\right\}$ NMR spectrum of $\mathbf{1 - N T f _ { 2 }}$ in $\mathrm{C}_{6} \mathrm{D}_{6}$. 
Table S1 Crystal and structure refinement details for 3, 4, and 5 .

\begin{tabular}{|c|c|c|c|}
\hline & 3 & 4 & 5 \\
\hline formula & $\mathrm{C}_{62} \mathrm{H}_{59.32} \mathrm{~B}_{4} \mathrm{~N}_{18} \mathrm{O}_{2} \mathrm{Sc}_{2}$ & $\mathrm{C}_{186} \mathrm{H}_{192} \mathrm{~B}_{12} \mathrm{~N}_{54} \mathrm{O}_{12} \mathrm{Sc}_{6}$ & $\begin{array}{c}\mathrm{C}_{62} \mathrm{H}_{62} \mathrm{~B}_{4} \mathrm{~N}_{18} \mathrm{O}_{2} \mathrm{Sc}_{2}, \\
2\left(\mathrm{C}_{2} \mathrm{~F}_{6} \mathrm{NO}_{4} \mathrm{~S}_{2}\right) \\
6\left(\mathrm{C}_{6} \mathrm{H}_{6}\right)\end{array}$ \\
\hline$f w$ & 1221.76 & 3775.33 & 2253.40 \\
\hline crystal system & monoclinic & trigonal & triclinic \\
\hline space group & $\mathrm{P} 2 / \mathrm{c}$ & R-3 & P-1 \\
\hline$a(\AA)$ & $17.2004(3)$ & $22.1407(3)$ & $13.8744(10)$ \\
\hline$b(\AA)$ & $11.8261(2)$ & $22.1407(3)$ & $14.4202(11)$ \\
\hline$c(\AA)$ & $15.3151(2)$ & $38.1488(7)$ & $15.9822(12)$ \\
\hline$\alpha(\operatorname{deg})$ & 90 & 90 & $64.748(3)$ \\
\hline$\beta$ (deg) & $104.3460(10)$ & 90 & $73.424(3)$ \\
\hline$\gamma(\mathrm{deg})$ & 90 & 120 & $70.000(3)$ \\
\hline$V\left(\AA^{3}\right)$ & $3018.16(8)$ & $16195.5(5)$ & $2680.8(4)$ \\
\hline$Z$ & 2 & 3 & 1 \\
\hline$T(\mathbf{K})$ & $173(2)$ & $173(2)$ & $173(2)$ \\
\hline Wavelength $(\AA)$ & 1.54178 & 1.54178 & 0.71073 \\
\hline$\rho_{\text {calcd }}\left(\mathrm{g} \cdot \mathrm{cm}^{-3}\right)$ & 1.344 & 1.159 & 1.396 \\
\hline$F(000)$ & 1270.6 & 5886 & 1164 \\
\hline$\mu\left(\mathrm{mm}^{-1}\right)$ & 2.416 & 2.062 & 0.293 \\
\hline crystal size, $\mathbf{m m}^{3}$ & $0.374 \times 0.121 \times 0.067$ & $0.100 \times 0.070 \times 0.050$ & $0.260 \times 0.200 \times 0.200$ \\
\hline transmission factors & $0.6383-0.9155$ & $0.6696-0.7536$ & $0.6392-0.7457$ \\
\hline$\theta$ range (deg) & $2.651-70.367$ & $2.579-72.392$ & $1.951-25.997$ \\
\hline data/restraints/param & $5706 / 1 / 408$ & $7119 / 0 / 412$ & $10516 / 72 / 692$ \\
\hline GOF & 1.034 & 1.015 & 1.039 \\
\hline$R_{1}[I>2 \sigma(I)]$ & 0.0425 & 0.0483 & 0.0708 \\
\hline $\mathrm{wR}_{2}$ [all data] & 0.1194 & 0.1456 & 0.2157 \\
\hline residual density, $\mathbf{e} / \AA^{3}$ & 0.288 and -0.574 & 0.280 and -0.285 & 0.753 and -0.866 \\
\hline
\end{tabular}




\section{Cartesian Coordinates of Optimized Structures}

\begin{tabular}{|c|c|c|c|}
\hline B & 3.66294500 & 7.82012900 & 4.25106500 \\
\hline B & 3.97856500 & 3.02020000 & 2.32989600 \\
\hline $\mathrm{C}$ & 4.36189700 & 6.75234900 & 3.23223500 \\
\hline $\mathrm{C}$ & 5.27247300 & 7.21174900 & 2.27190000 \\
\hline $\mathrm{H}$ & 5.55825000 & 8.25801000 & 2.26916300 \\
\hline $\mathrm{C}$ & 5.76244600 & 6.34946200 & 1.30269600 \\
\hline $\mathrm{H}$ & 6.43465300 & 6.70796600 & 0.52549400 \\
\hline $\mathrm{C}$ & 5.38154500 & 5.01678800 & 1.35393100 \\
\hline $\mathrm{H}$ & 5.75504300 & 4.31146500 & 0.61941800 \\
\hline $\mathrm{C}$ & 4.48314400 & 4.57440900 & 2.33286700 \\
\hline $\mathrm{C}$ & 2.53878200 & 5.82340400 & 7.12662300 \\
\hline $\mathrm{H}$ & 1.93188100 & 5.00576100 & 7.48337600 \\
\hline $\mathrm{C}$ & 3.36710300 & 6.69767200 & 7.82704200 \\
\hline $\mathrm{H}$ & 3.57332600 & 6.71976700 & 8.88724300 \\
\hline $\mathrm{C}$ & 3.86740500 & 7.54411800 & 6.84904200 \\
\hline $\mathrm{H}$ & 4.54346700 & 8.38073300 & 6.92749200 \\
\hline $\mathrm{C}$ & 0.59492300 & 7.54316600 & 2.31507400 \\
\hline $\mathrm{H}$ & -0.17481400 & 6.90164000 & 1.90964500 \\
\hline $\mathrm{C}$ & 0.88072300 & 8.86430700 & 1.97180300 \\
\hline $\mathrm{H}$ & 0.36796400 & 9.49514000 & 1.26051800 \\
\hline $\mathrm{C}$ & 1.98051800 & 9.18137800 & 2.75252600 \\
\hline $\mathrm{H}$ & 2.56583700 & 10.08666300 & 2.80286700 \\
\hline $\mathrm{C}$ & 3.14562900 & 2.54205100 & 5.87121300 \\
\hline $\mathrm{H}$ & 2.64010000 & 2.89398100 & 6.75893700 \\
\hline $\mathrm{C}$ & 4.05698600 & 1.49366800 & 5.75530200 \\
\hline $\mathrm{H}$ & 4.40315100 & 0.82132900 & 6.52656900 \\
\hline $\mathrm{C}$ & 4.42165200 & 1.51282900 & 4.41993700 \\
\hline $\mathrm{H}$ & 5.10726500 & 0.88533000 & 3.87320600 \\
\hline $\mathrm{C}$ & 0.62694500 & 3.93537300 & 1.20467300 \\
\hline $\mathrm{H}$ & -0.28724300 & 4.45739400 & 1.44201500 \\
\hline $\mathrm{C}$ & 1.02357400 & 3.30977500 & 0.02406200 \\
\hline $\mathrm{H}$ & 0.48159200 & 3.23319700 & -0.90736900 \\
\hline $\mathrm{C}$ & 2.28198700 & 2.80266100 & 0.31801600 \\
\hline $\mathrm{H}$ & 2.97980700 & 2.25888800 & -0.30050000 \\
\hline $\mathrm{C}$ & 4.48428300 & 9.18576900 & 4.56479000 \\
\hline $\mathrm{C}$ & 3.82661800 & 10.34871100 & 5.00878200 \\
\hline $\mathrm{H}$ & 2.74034200 & 10.35699600 & 5.07623800 \\
\hline $\mathrm{C}$ & 4.51727000 & 11.49313100 & 5.40200500 \\
\hline $\mathrm{H}$ & 3.96016800 & 12.36782800 & 5.73471600 \\
\hline $\mathrm{C}$ & 5.91573600 & 11.53226600 & 5.39082700 \\
\hline
\end{tabular}




\begin{tabular}{|c|c|c|c|}
\hline $\mathrm{C}$ & 6.58737400 & 10.37208600 & 4.99520200 \\
\hline $\mathrm{H}$ & 7.67619700 & 10.35587400 & 5.00330900 \\
\hline $\mathrm{C}$ & 5.88833100 & 9.23236000 & 4.59729600 \\
\hline $\mathrm{H}$ & 6.46036000 & 8.34851900 & 4.32446600 \\
\hline $\mathrm{C}$ & 6.66574800 & 12.77854700 & 5.78179400 \\
\hline $\mathrm{H}$ & 6.14145900 & 13.33391400 & 6.5675440 \\
\hline $\mathrm{H}$ & 7.67185400 & 12.54448100 & 6.1460940 \\
\hline $\mathrm{H}$ & 6.77918400 & 13.45795300 & 4.9262240 \\
\hline $\mathrm{C}$ & 4.95421600 & 1.92928900 & 1.62371500 \\
\hline $\mathrm{C}$ & 6.35452100 & 2.05328900 & 1.62905700 \\
\hline $\mathrm{H}$ & 6.81160100 & 2.94624100 & 2.04876100 \\
\hline $\mathrm{C}$ & 7.19399400 & 1.05393000 & 1.13816400 \\
\hline $\mathrm{H}$ & 8.27272400 & 1.20043000 & 1.16643200 \\
\hline $\mathrm{C}$ & 6.67652800 & -0.13667800 & 0.61921700 \\
\hline $\mathrm{C}$ & 5.28726400 & -0.29613700 & 0.64149700 \\
\hline $\mathrm{H}$ & 4.84910300 & -1.22382000 & 0.27611900 \\
\hline $\mathrm{C}$ & 4.45552100 & 0.70619300 & 1.13769000 \\
\hline $\mathrm{H}$ & 3.38522800 & 0.51248600 & 1.16997800 \\
\hline $\mathrm{C}$ & 7.57773100 & -1.20185600 & 0.05204000 \\
\hline $\mathrm{H}$ & 8.56699800 & -1.18350800 & 0.52220600 \\
\hline $\mathrm{H}$ & 7.15460500 & -2.20279800 & 0.19154400 \\
\hline $\mathrm{H}$ & 7.72841800 & -1.06121200 & -1.02689300 \\
\hline $\mathrm{N}$ & 3.93458300 & 5.46136900 & 3.20744300 \\
\hline $\mathrm{N}$ & 2.54219200 & 6.11766200 & 5.81786500 \\
\hline $\mathrm{N}$ & 3.35934700 & 7.17982800 & 5.65416800 \\
\hline $\mathrm{N}$ & 1.45396600 & 7.09119400 & 3.24108600 \\
\hline $\mathrm{N}$ & 2.29730500 & 8.11544900 & 3.51531300 \\
\hline $\mathrm{N}$ & 2.96773000 & 3.15203900 & 4.69073400 \\
\hline $\mathrm{N}$ & 3.75984800 & 2.51409800 & 3.80080000 \\
\hline $\mathrm{N}$ & 1.57711800 & 3.81526500 & 2.14614000 \\
\hline $\mathrm{N}$ & 2.58438600 & 3.09964000 & 1.59595200 \\
\hline $\mathrm{Sc}$ & 1.64598300 & 4.93379100 & 4.13957200 \\
\hline B & -4.37229800 & 6.26385900 & 5.76727100 \\
\hline B & -3.06675400 & 1.33488600 & 6.65538800 \\
\hline $\mathrm{C}$ & -4.63367100 & 4.86065300 & 6.56341200 \\
\hline $\mathrm{C}$ & -5.61253600 & 4.78017500 & 7.56031100 \\
\hline $\mathrm{H}$ & -6.17436900 & 5.66924400 & $7.8255260 \mathrm{c}$ \\
\hline $\mathrm{C}$ & -5.85070400 & 3.57836400 & 8.21178400 \\
\hline $\mathrm{H}$ & -6.60003500 & 3.50965800 & 8.99803600 \\
\hline $\mathrm{C}$ & -5.11763900 & 2.46461100 & 7.83131300 \\
\hline $\mathrm{H}$ & -5.28981500 & 1.50734000 & 8.3111790 \\
\hline $\mathrm{C}$ & -4.10138000 & 2.58069700 & 6.87277900 \\
\hline $\mathrm{C}$ & -3.22753700 & 4.86775100 & 2.57421100 \\
\hline $\mathrm{H}$ & -2.56034900 & 4.18571000 & 2.0661910 \\
\hline $\mathrm{C}$ & -4.28861200 & 5.61946600 & 2.06464900 \\
\hline $\mathrm{H}$ & -4.64234900 & 5.67182500 & 1.04514700 \\
\hline
\end{tabular}




$\begin{array}{lrcc}\mathrm{C} & -4.79715300 & 6.28042500 & 3.17136800 \\ \mathrm{H} & -5.62335600 & 6.96831100 & 3.25803900 \\ \mathrm{C} & -1.01371000 & 6.89492300 & 7.11318800 \\ \mathrm{H} & 0.02049500 & 6.58180000 & 7.15100100 \\ \mathrm{C} & -1.64518300 & 7.95987100 & 7.75308500 \\ \mathrm{H} & -1.21551900 & 8.67656500 & 8.43761200 \\ \mathrm{C} & -2.95683100 & 7.89863300 & 7.30112900 \\ \mathrm{H} & -3.80836800 & 8.51712100 & 7.54050300 \\ \mathrm{C} & -1.45568200 & 1.73432200 & 3.35646800 \\ \mathrm{H} & -0.86435700 & 2.35344700 & 2.69613600 \\ \mathrm{C} & -1.91405200 & 0.42963700 & 3.18372200 \\ \mathrm{H} & -1.77696700 & -0.21858100 & 2.33063700 \\ \mathrm{C} & -2.57835700 & 0.14257700 & 4.36689800 \\ \mathrm{H} & -3.08198200 & -0.75703400 & 4.68322600 \\ \mathrm{C} & -0.59294300 & 3.30625600 & 8.44811900 \\ \mathrm{H} & -0.03130100 & 4.22972500 & 8.47561200 \\ \mathrm{C} & -0.76043600 & 2.34039100 & 9.44312000 \\ \mathrm{H} & -0.34103100 & 2.32544000 & 10.43867700 \\ \mathrm{C} & -1.59991300 & 1.40159500 & 8.86225000 \\ \mathrm{H} & -2.02206600 & 0.49448500 & 9.26721900 \\ \mathrm{C} & -5.58650600 & 7.34554200 & 5.74095800 \\ \mathrm{C} & -5.34925400 & 8.70991100 & 5.48965700 \\ \mathrm{H} & -4.32707600 & 9.06742300 & 5.38534300 \\ \mathrm{C} & -6.38184700 & 9.63322600 & 5.33164900 \\ \mathrm{H} & -6.14113500 & 10.67806300 & 5.14101000 \\ \mathrm{H} & -7.72106800 & 9.23802800 & 5.39854900 \\ \mathrm{C} & -7.97823500 & 7.87827400 & 5.59955100 \\ \mathrm{C} & -9.00870900 & 7.52663600 & 5.62266800 \\ \mathrm{H} & -6.93972100 & 6.96230300 & 5.76011500 \\ \mathrm{C} & -7.19825600 & 5.91311900 & 5.87836700 \\ \mathrm{H} & -8.84140100 & 10.23562700 & 5.26455000 \\ \mathrm{C} & -8.52899600 & 11.11626400 & 4.69287200 \\ \mathrm{H} & -9.71227300 & 9.79796200 & 4.76390300 \\ \mathrm{H} & -9.17786600 & 10.58910900 & 6.24858900 \\ \mathrm{H} & -3.61744500 & -0.14164800 & 7.03836900 \\ \mathrm{C} & -4.95441400 & -0.51763800 & 6.82067400 \\ \mathrm{H} & -5.66492600 & 0.22168600 & 6.45727500 \\ \mathrm{C} & -5.40558000 & -1.81975200 & 7.03266900 \\ \mathrm{H} & -6.45141100 & -2.06056500 & 6.84774300 \\ \mathrm{H} & -3.53714700 & -2.82417200 & 7.47174700 \\ \mathrm{H} & -2.75390300 & -3.24142700 & 7.96980400 \\ \mathrm{H} & -1.17510000 & 7.43817100 \\ \mathrm{H} & -0.96964600 & 7.55495500 \\ \mathrm{H} & -48700 & -4.22188300 & 7.74107700 \\ \mathrm{H} & -4.49118000 & 7.07738700\end{array}$




$\begin{array}{lrrr}\mathrm{H} & -4.23306600 & -4.96160500 & 7.60567300 \\ \mathrm{H} & -5.39450000 & -4.32232400 & 8.77223900 \\ \mathrm{~N} & -3.84417100 & 3.78368100 & 6.29606800 \\ \mathrm{~N} & -3.10741500 & 5.06210500 & 3.89324800 \\ \mathrm{~N} & -4.07268800 & 5.93104200 & 4.25744800 \\ \mathrm{~N} & -1.88719900 & 6.23313900 & 6.33762700 \\ \mathrm{~N} & -3.07624700 & 6.87304400 & 6.43714400 \\ \mathrm{~N} & -1.82958600 & 2.20148100 & 4.55599800 \\ \mathrm{~N} & -2.51436000 & 1.21627900 & 5.18134700 \\ \mathrm{~N} & -1.28013400 & 2.97349100 & 7.34678900 \\ \mathrm{~N} & -1.88343500 & 1.79079300 & 7.60187200 \\ \mathrm{O} & -0.42961800 & 5.07426400 & 3.79106300 \\ \mathrm{Sc} & -1.56021100 & 4.23185200 & 5.36842200 \\ \mathrm{O} & 0.52423600 & 4.06954700 & 5.69489900 \\ \mathrm{H} & 0.76148300 & 3.24705100 & 6.14105600 \\ \mathrm{H} & -0.87822100 & 5.84348100 & 3.41905700\end{array}$

$\begin{array}{lrrr} & & & \\ & & & \\ \mathrm{Sc}-\mathrm{O}^{\prime}-\mathrm{H}-\mathrm{Sc} & \mathrm{TS} & & \\ \mathrm{B} & 3.66294500 & 7.82012900 & 4.25106500 \\ \mathrm{~B} & 3.97856500 & 3.02020000 & 2.32989600 \\ \mathrm{C} & 4.36189700 & 6.75234900 & 3.23223500 \\ \mathrm{C} & 5.27247300 & 7.21174900 & 2.27190000 \\ \mathrm{H} & 5.55825000 & 8.25801000 & 2.26916300 \\ \mathrm{C} & 5.76244600 & 6.34946200 & 1.30269600 \\ \mathrm{H} & 6.43465300 & 6.70796600 & 0.52549400 \\ \mathrm{C} & 5.38154500 & 5.01678800 & 1.35393100 \\ \mathrm{H} & 5.75504300 & 4.31146500 & 0.61941800 \\ \mathrm{C} & 4.48314400 & 4.57440900 & 2.33286700 \\ \mathrm{C} & 2.53878200 & 5.82340400 & 7.12662300 \\ \mathrm{H} & 1.93188100 & 5.00576100 & 7.48337600 \\ \mathrm{C} & 3.36710300 & 6.69767200 & 7.82704200 \\ \mathrm{H} & 3.57332600 & 6.71976700 & 8.88724300 \\ \mathrm{C} & 3.86740500 & 7.54411800 & 6.84904200 \\ \mathrm{H} & 4.54346700 & 8.38073300 & 6.92749200 \\ \mathrm{C} & 0.59492300 & 7.54316600 & 2.31507400 \\ \mathrm{H} & -0.17481400 & 6.90164000 & 1.90964500 \\ \mathrm{C} & 0.88072300 & 8.86430700 & 1.97180300 \\ \mathrm{H} & 0.36796400 & 9.49514000 & 1.26051800 \\ \mathrm{C} & 1.98051800 & 9.18137800 & 2.75252600 \\ \mathrm{H} & 2.56583700 & 10.08666300 & 2.80286700 \\ \mathrm{C} & 3.14562900 & 2.54205100 & 5.87121300 \\ \mathrm{H} & 2.64010000 & 2.89398100 & 6.75893700 \\ \mathrm{C} & 4.05698600 & 1.49366800 & 5.75530200 \\ \mathrm{H} & 4.40315100 & 0.82132900 & 6.52656900\end{array}$




\begin{tabular}{|c|c|c|c|}
\hline $\mathrm{C}$ & 4.42165200 & 1.51282900 & 4.41993700 \\
\hline $\mathrm{H}$ & 5.10726500 & 0.88533000 & 3.87320600 \\
\hline $\mathrm{C}$ & 0.62694500 & 3.93537300 & 1.20467300 \\
\hline $\mathrm{H}$ & -0.28724300 & 4.45739400 & 1.44201500 \\
\hline $\mathrm{C}$ & 1.02357400 & 3.30977500 & 0.02406200 \\
\hline $\mathrm{H}$ & 0.48159200 & 3.23319700 & -0.90736900 \\
\hline $\mathrm{C}$ & 2.28198700 & 2.80266100 & 0.31801600 \\
\hline $\mathrm{H}$ & 2.97980700 & 2.25888800 & -0.30050000 \\
\hline $\mathrm{C}$ & 4.48428300 & 9.18576900 & 4.56479000 \\
\hline $\mathrm{C}$ & 3.82661800 & 10.34871100 & 5.00878200 \\
\hline $\mathrm{H}$ & 2.74034200 & 10.35699600 & 5.07623800 \\
\hline $\mathrm{C}$ & 4.51727000 & 11.49313100 & 5.40200500 \\
\hline $\mathrm{H}$ & 3.96016800 & 12.36782800 & 5.73471600 \\
\hline $\mathrm{C}$ & 5.91573600 & 11.53226600 & 5.39082700 \\
\hline $\mathrm{C}$ & 6.58737400 & 10.37208600 & 4.99520200 \\
\hline $\mathrm{H}$ & 7.67619700 & 10.35587400 & 5.003309 \\
\hline $\mathrm{C}$ & 5.88833100 & 9.23236000 & 4.59729600 \\
\hline $\mathrm{H}$ & 6.46036000 & 8.34851900 & 4.32446600 \\
\hline $\mathrm{C}$ & 6.66574800 & 12.77854700 & 5.78179400 \\
\hline $\mathrm{H}$ & 6.14145900 & 13.33391400 & $6.5675440 \mathrm{C}$ \\
\hline $\mathrm{H}$ & 7.67185400 & 12.54448100 & 6.14609400 \\
\hline $\mathrm{H}$ & 6.77918400 & 13.45795300 & 4.92622400 \\
\hline $\mathrm{C}$ & 4.95421600 & 1.92928900 & 1.62371500 \\
\hline $\mathrm{C}$ & 6.35452100 & 2.05328900 & 1.62905700 \\
\hline $\mathrm{H}$ & 6.81160100 & 2.94624100 & 2.04876100 \\
\hline $\mathrm{C}$ & 7.19399400 & 1.05393000 & 1.13816400 \\
\hline $\mathrm{H}$ & 8.27272400 & 1.20043000 & 1.16643200 \\
\hline $\mathrm{C}$ & 6.67652800 & -0.13667800 & 0.61921700 \\
\hline $\mathrm{C}$ & 5.28726400 & -0.29613700 & 0.64149700 \\
\hline $\mathrm{H}$ & 4.84910300 & -1.22382000 & 0.27611900 \\
\hline $\mathrm{C}$ & 4.45552100 & 0.70619300 & 1.13769000 \\
\hline $\mathrm{H}$ & 3.38522800 & 0.51248600 & 1.16997800 \\
\hline $\mathrm{C}$ & 7.57773100 & -1.20185600 & 0.05204000 \\
\hline $\mathrm{H}$ & 8.56699800 & -1.18350800 & 0.52220600 \\
\hline $\mathrm{H}$ & 7.15460500 & -2.20279800 & 0.19154400 \\
\hline $\mathrm{H}$ & 7.72841800 & -1.06121200 & -1.0268930 \\
\hline $\mathrm{N}$ & 3.93458300 & 5.46136900 & 3.20744300 \\
\hline $\mathrm{N}$ & 2.54219200 & 6.11766200 & 5.81786500 \\
\hline $\mathrm{N}$ & 3.35934700 & 7.17982800 & 5.65416800 \\
\hline $\mathrm{N}$ & 1.45396600 & 7.09119400 & 3.24108600 \\
\hline $\mathrm{N}$ & 2.29730500 & 8.11544900 & 3.51531300 \\
\hline $\mathrm{N}$ & 2.96773000 & 3.15203900 & 4.6907340 \\
\hline $\mathrm{N}$ & 3.75984800 & 2.51409800 & $3.8008000 \mathrm{C}$ \\
\hline $\mathrm{N}$ & 1.57711800 & 3.81526500 & 2.1461400 \\
\hline $\mathrm{N}$ & 2.58438600 & 3.09964000 & 1.59595200 \\
\hline $\mathrm{Sc}$ & 1.64598300 & 4.93379100 & 4.13957200 \\
\hline
\end{tabular}




\begin{tabular}{|c|c|c|c|}
\hline B & -4.37229800 & 6.26385900 & 5.76727100 \\
\hline B & -3.06675400 & 1.33488600 & 6.65538800 \\
\hline $\mathrm{C}$ & -4.63367100 & 4.86065300 & 6.56341200 \\
\hline $\mathrm{C}$ & -5.61253600 & 4.78017500 & 7.56031100 \\
\hline $\mathrm{H}$ & -6.17436900 & 5.66924400 & 7.82552600 \\
\hline $\mathrm{C}$ & -5.85070400 & 3.57836400 & 8.21178400 \\
\hline $\mathrm{H}$ & -6.60003500 & 3.50965800 & 8.99803600 \\
\hline $\mathrm{C}$ & -5.11763900 & 2.46461100 & 7.83131300 \\
\hline $\mathrm{H}$ & -5.28981500 & 1.50734000 & 8.31117900 \\
\hline $\mathrm{C}$ & -4.10138000 & 2.58069700 & 6.87277900 \\
\hline $\mathrm{C}$ & -3.22753700 & 4.86775100 & 2.57421100 \\
\hline $\mathrm{H}$ & -2.56034900 & 4.18571000 & 2.06619100 \\
\hline $\mathrm{C}$ & -4.28861200 & 5.61946600 & 2.06464900 \\
\hline $\mathrm{H}$ & -4.64234900 & 5.67182500 & 1.04514700 \\
\hline $\mathrm{C}$ & -4.79715300 & 6.28042500 & 3.17136800 \\
\hline $\mathrm{H}$ & -5.62335600 & 6.96831100 & 3.25803900 \\
\hline $\mathrm{C}$ & -1.01371000 & 6.89492300 & 7.11318800 \\
\hline $\mathrm{H}$ & 0.02049500 & 6.58180000 & 7.15100100 \\
\hline $\mathrm{C}$ & -1.64518300 & 7.95987100 & 7.75308500 \\
\hline $\mathrm{H}$ & -1.21551900 & 8.67656500 & 8.43761200 \\
\hline $\mathrm{C}$ & -2.95683100 & 7.89863300 & 7.30112900 \\
\hline $\mathrm{H}$ & -3.80836800 & 8.51712100 & 7.54050300 \\
\hline $\mathrm{C}$ & -1.45568200 & 1.73432200 & 3.35646800 \\
\hline $\mathrm{H}$ & -0.86435700 & 2.35344700 & 2.69613600 \\
\hline $\mathrm{C}$ & -1.91405200 & 0.42963700 & 3.18372200 \\
\hline $\mathrm{H}$ & -1.77696700 & -0.21858100 & 2.33063700 \\
\hline $\mathrm{C}$ & -2.57835700 & 0.14257700 & 4.36689800 \\
\hline $\mathrm{H}$ & -3.08198200 & -0.75703400 & 4.68322600 \\
\hline $\mathrm{C}$ & -0.59294300 & 3.30625600 & 8.44811900 \\
\hline $\mathrm{H}$ & -0.03130100 & 4.22972500 & 8.47561200 \\
\hline $\mathrm{C}$ & -0.76043600 & 2.34039100 & 9.44312000 \\
\hline $\mathrm{H}$ & -0.34103100 & 2.32544000 & 10.43867700 \\
\hline $\mathrm{C}$ & -1.59991300 & 1.40159500 & 8.86225000 \\
\hline $\mathrm{H}$ & -2.02206600 & 0.49448500 & 9.26721900 \\
\hline $\mathrm{C}$ & -5.58650600 & 7.34554200 & 5.74095800 \\
\hline $\mathrm{C}$ & -5.34925400 & 8.70991100 & 5.48965700 \\
\hline $\mathrm{H}$ & -4.32707600 & 9.06742300 & 5.38534300 \\
\hline $\mathrm{C}$ & -6.38184700 & 9.63322600 & 5.33164900 \\
\hline $\mathrm{H}$ & -6.14113500 & 10.67806300 & 5.14101000 \\
\hline $\mathrm{C}$ & -7.72106800 & 9.23802800 & 5.39854900 \\
\hline $\mathrm{C}$ & -7.97823500 & 7.87827400 & 5.59955100 \\
\hline $\mathrm{H}$ & -9.00870900 & 7.52663600 & 5.62266800 \\
\hline $\mathrm{C}$ & -6.93972100 & 6.96230300 & 5.76011500 \\
\hline $\mathrm{H}$ & -7.19825600 & 5.91311900 & 5.87836700 \\
\hline $\mathrm{C}$ & -8.84140100 & 10.23562700 & 5.26455000 \\
\hline $\mathrm{H}$ & -8.52899600 & 11.11626400 & 4.69287200 \\
\hline
\end{tabular}




\begin{tabular}{|c|c|c|c|}
\hline $\mathrm{H}$ & -9.71227300 & 9.79796200 & 4.76390300 \\
\hline $\mathrm{H}$ & -9.17786600 & 10.58910900 & 6.24858900 \\
\hline $\mathrm{C}$ & -3.61744500 & -0.14164800 & 7.03836900 \\
\hline $\mathrm{C}$ & -4.95441400 & -0.51763800 & 6.82067400 \\
\hline $\mathrm{H}$ & -5.66492600 & 0.22168600 & 6.45727500 \\
\hline $\mathrm{C}$ & -5.40558000 & -1.81975200 & 7.03266900 \\
\hline $\mathrm{H}$ & -6.45141100 & -2.06056500 & 6.84774300 \\
\hline $\mathrm{C}$ & -4.53714700 & -2.82417200 & 7.47174700 \\
\hline $\mathrm{C}$ & -3.19519100 & -2.47773700 & 7.65870600 \\
\hline $\mathrm{H}$ & -2.48390300 & -3.24142700 & 7.96980400 \\
\hline $\mathrm{C}$ & -2.75090500 & -1.17510000 & 7.43817100 \\
\hline $\mathrm{H}$ & -1.68859300 & -0.96964600 & 7.55495500 \\
\hline $\mathrm{C}$ & -5.02959700 & -4.22188300 & 7.74107700 \\
\hline $\mathrm{H}$ & -5.85867500 & -4.49118000 & 7.07738700 \\
\hline $\mathrm{H}$ & -4.23306600 & -4.96160500 & 7.60567300 \\
\hline $\mathrm{H}$ & -5.39450000 & -4.32232400 & 8.77223900 \\
\hline $\mathrm{N}$ & -3.84417100 & 3.78368100 & 6.29606800 \\
\hline $\mathrm{N}$ & -3.10741500 & 5.06210500 & 3.89324800 \\
\hline $\mathrm{N}$ & -4.07268800 & 5.93104200 & 4.25744800 \\
\hline $\mathrm{N}$ & -1.88719900 & 6.23313900 & 6.33762700 \\
\hline $\mathrm{N}$ & -3.07624700 & 6.87304400 & 6.43714400 \\
\hline $\mathrm{N}$ & -1.82958600 & 2.20148100 & 4.55599800 \\
\hline $\mathrm{N}$ & -2.51436000 & 1.21627900 & 5.18134700 \\
\hline $\mathrm{N}$ & -1.28013400 & 2.97349100 & 7.34678900 \\
\hline $\mathrm{N}$ & -1.88343500 & 1.79079300 & 7.60187200 \\
\hline $\mathrm{O}$ & -0.42961800 & 5.07426400 & 3.79106300 \\
\hline $\mathrm{Sc}$ & -1.56021100 & 4.23185200 & 5.36842200 \\
\hline $\mathrm{O}$ & 0.52423600 & 4.06954700 & 5.69489900 \\
\hline $\mathrm{H}$ & 0.76148300 & 3.24705100 & 6.14105600 \\
\hline $\mathrm{H}$ & -0.87822100 & 5.84348100 & 3.41905700 \\
\hline \multicolumn{4}{|c|}{$\mathrm{H}_{\mathrm{O}}-\mathrm{H}$} \\
\hline B & 4.61228000 & 7.39540700 & 4.83636400 \\
\hline B & 3.55782000 & 3.28521000 & 1.90481600 \\
\hline $\mathrm{C}$ & 5.01931400 & 6.43163400 & 3.58096900 \\
\hline $\mathrm{C}$ & 6.07708800 & 6.78284800 & 2.73249900 \\
\hline $\mathrm{H}$ & 6.66562400 & 7.66736800 & 2.95197300 \\
\hline $\mathrm{C}$ & 6.34372700 & 6.02789900 & 1.59904400 \\
\hline $\mathrm{H}$ & 7.13907100 & 6.31636400 & 0.91444400 \\
\hline $\mathrm{C}$ & 5.58140500 & 4.89240500 & 1.36088100 \\
\hline $\mathrm{H}$ & 5.77264400 & 4.27482300 & 0.48977900 \\
\hline $\mathrm{C}$ & 4.53294000 & 4.55582700 & 2.22526000 \\
\hline $\mathrm{C}$ & 2.78821300 & 5.18815600 & 7.15966000 \\
\hline $\mathrm{H}$ & 1.96379300 & 4.51083600 & 7.32535100 \\
\hline
\end{tabular}




\begin{tabular}{|c|c|c|c|}
\hline $\mathrm{C}$ & 3.77658300 & 5.61060600 & 8.04724600 \\
\hline $\mathrm{H}$ & 3.91097100 & 5.32834500 & 9.08119600 \\
\hline $\mathrm{C}$ & 4.55387200 & 6.48100500 & 7.29843700 \\
\hline $\mathrm{H}$ & 5.42861000 & 7.04911000 & 7.57323400 \\
\hline $\mathrm{C}$ & 1.57794800 & 8.61193400 & 3.18011900 \\
\hline $\mathrm{H}$ & 0.59424500 & 8.38464200 & 2.78997300 \\
\hline $\mathrm{C}$ & 2.28619900 & 9.81252200 & 3.13330900 \\
\hline $\mathrm{H}$ & 1.98503300 & 10.74355600 & 2.67562500 \\
\hline $\mathrm{C}$ & 3.46536900 & 9.54303800 & 3.81160100 \\
\hline $\mathrm{H}$ & 4.32214300 & 10.17051700 & 4.00435800 \\
\hline $\mathrm{C}$ & 2.12789000 & 2.39632100 & 5.18587600 \\
\hline $\mathrm{H}$ & 1.53208600 & 2.69034200 & 6.03829500 \\
\hline $\mathrm{C}$ & 2.73204600 & 1.17037200 & 4.91152300 \\
\hline $\mathrm{H}$ & 2.73487600 & 0.27750700 & 5.51909900 \\
\hline $\mathrm{C}$ & 3.31078100 & 1.34901400 & 3.66449900 \\
\hline $\mathrm{H}$ & 3.87567100 & 0.66405300 & 3.05187300 \\
\hline $\mathrm{C}$ & 0.74179200 & 5.43944500 & 0.96464500 \\
\hline $\mathrm{H}$ & 0.02827500 & 6.18899500 & 1.29123600 \\
\hline $\mathrm{C}$ & 0.97087800 & 4.90929100 & -0.30638100 \\
\hline $\mathrm{H}$ & 0.47611500 & 5.16347800 & -1.23262500 \\
\hline $\mathrm{C}$ & 1.98604900 & 3.98181300 & -0.11561800 \\
\hline $\mathrm{H}$ & 2.49785000 & 3.34777100 & -0.82367300 \\
\hline $\mathrm{C}$ & 5.80355400 & 8.31207900 & 5.45174800 \\
\hline $\mathrm{C}$ & 5.53848200 & 9.49547200 & 6.16560900 \\
\hline $\mathrm{H}$ & 4.51385200 & 9.85059900 & 6.25505500 \\
\hline $\mathrm{C}$ & 6.54203300 & 10.22591000 & 6.79983900 \\
\hline $\mathrm{H}$ & 6.28327000 & 11.13777800 & 7.33610400 \\
\hline $\mathrm{C}$ & 7.87371400 & 9.79963000 & 6.77211000 \\
\hline $\mathrm{C}$ & 8.15024900 & 8.60156800 & 6.10644300 \\
\hline $\mathrm{H}$ & 9.17083700 & 8.22190000 & 6.09010700 \\
\hline $\mathrm{C}$ & 7.14143300 & 7.88067200 & 5.46868500 \\
\hline $\mathrm{H}$ & 7.40722300 & 6.94247400 & 4.98719300 \\
\hline $\mathrm{C}$ & 8.96723900 & 10.60357400 & 7.42507100 \\
\hline $\mathrm{H}$ & 8.58819000 & 11.18317900 & 8.27390900 \\
\hline $\mathrm{H}$ & 9.77707400 & 9.96117600 & 7.78810400 \\
\hline $\mathrm{H}$ & 9.41176500 & 11.31670200 & 6.71765800 \\
\hline $\mathrm{C}$ & 4.18912900 & 2.08808000 & 1.00753200 \\
\hline $\mathrm{C}$ & 5.55669900 & 1.76574600 & 1.03758000 \\
\hline $\mathrm{H}$ & 6.23892800 & 2.38003400 & 1.62031900 \\
\hline $\mathrm{C}$ & 6.07761300 & 0.66052700 & 0.36480600 \\
\hline $\mathrm{H}$ & 7.14548400 & 0.45477300 & 0.42135800 \\
\hline $\mathrm{C}$ & 5.25282300 & -0.19242200 & -0.37399200 \\
\hline $\mathrm{C}$ & 3.88263400 & 0.08934200 & -0.38471400 \\
\hline $\mathrm{H}$ & 3.20483800 & -0.57114700 & -0.92371100 \\
\hline $\mathrm{C}$ & 3.36981700 & 1.19245100 & 0.29474100 \\
\hline $\mathrm{H}$ & 2.29195500 & 1.34224500 & 0.28674100 \\
\hline
\end{tabular}




\begin{tabular}{|c|c|c|c|}
\hline $\mathrm{C}$ & 5.81609500 & -1.36372500 & -1.13511100 \\
\hline $\mathrm{H}$ & 6.74669000 & -1.72564900 & -0.68469200 \\
\hline $\mathrm{H}$ & 5.10835700 & -2.19953900 & -1.16877800 \\
\hline $\mathrm{H}$ & 6.04296000 & -1.08980200 & -2.17437400 \\
\hline $\mathrm{N}$ & 4.23416900 & 5.36493100 & 3.27628400 \\
\hline $\mathrm{N}$ & 2.95839100 & 5.76176300 & 5.96179200 \\
\hline $\mathrm{N}$ & 4.04711500 & 6.56007600 & 6.05078900 \\
\hline $\mathrm{N}$ & 2.28502900 & 7.67868700 & 3.83953500 \\
\hline $\mathrm{N}$ & 3.43919200 & 8.26908400 & 4.24656100 \\
\hline $\mathrm{N}$ & 2.33691600 & 3.25578600 & 4.18120200 \\
\hline $\mathrm{N}$ & 3.06112700 & 2.60551200 & 3.24002600 \\
\hline $\mathrm{N}$ & 1.56639800 & 4.86807800 & 1.85741900 \\
\hline $\mathrm{N}$ & 2.31624400 & 3.95636300 & 1.18995600 \\
\hline Sc & 1.90399600 & 5.43767300 & 4.02185400 \\
\hline B & -4.81901600 & 5.86003500 & 4.92701700 \\
\hline B & -2.27752400 & 2.03027400 & 7.26387500 \\
\hline $\mathrm{C}$ & -4.79055200 & 4.70644100 & 6.08376600 \\
\hline $\mathrm{C}$ & -5.80724600 & 4.62987800 & 7.04369600 \\
\hline $\mathrm{H}$ & -6.63928200 & 5.32410000 & 6.99506900 \\
\hline $\mathrm{C}$ & -5.73246600 & 3.69369700 & 8.06569700 \\
\hline $\mathrm{H}$ & -6.50486400 & 3.64452700 & 8.83076900 \\
\hline $\mathrm{C}$ & -4.65491900 & 2.81910700 & 8.09072900 \\
\hline $\mathrm{H}$ & -4.57337200 & 2.07388300 & 8.87478800 \\
\hline $\mathrm{C}$ & -3.63954300 & 2.92550800 & 7.13222800 \\
\hline $\mathrm{C}$ & -2.77300300 & 4.42007900 & 2.20360800 \\
\hline $\mathrm{H}$ & -1.81952500 & 4.02358800 & 1.88327500 \\
\hline $\mathrm{C}$ & -3.94111000 & 4.62246000 & 1.46949600 \\
\hline $\mathrm{H}$ & -4.12301200 & 4.39633600 & 0.42906400 \\
\hline $\mathrm{C}$ & -4.82171600 & 5.18908500 & 2.37924200 \\
\hline $\mathrm{H}$ & -5.84201300 & 5.51530800 & 2.25239900 \\
\hline $\mathrm{C}$ & -1.98367700 & 7.78580200 & 6.24094800 \\
\hline $\mathrm{H}$ & -0.91591700 & 7.81498800 & 6.41419200 \\
\hline $\mathrm{C}$ & -2.95839700 & 8.74378500 & 6.51627400 \\
\hline $\mathrm{H}$ & -2.83357600 & 9.70718600 & 6.98854700 \\
\hline $\mathrm{C}$ & -4.13206600 & 8.18576400 & 6.02589700 \\
\hline $\mathrm{H}$ & -5.14200100 & 8.56685700 & 6.02855000 \\
\hline $\mathrm{C}$ & -0.86139200 & 1.87573400 & 3.86231200 \\
\hline $\mathrm{H}$ & -0.44938200 & 2.41003400 & 3.01708700 \\
\hline $\mathrm{C}$ & -0.99624300 & 0.50368800 & 4.06735900 \\
\hline $\mathrm{H}$ & -0.73251100 & -0.29984100 & 3.39576500 \\
\hline $\mathrm{C}$ & -1.52072600 & 0.39982200 & 5.34697600 \\
\hline $\mathrm{H}$ & -1.77693100 & -0.47204700 & 5.92828900 \\
\hline $\mathrm{C}$ & -0.43394500 & 5.02374900 & 8.28960800 \\
\hline $\mathrm{H}$ & -0.07610600 & 6.00687600 & 8.01629100 \\
\hline $\mathrm{C}$ & -0.42983500 & 4.39456100 & 9.53456300 \\
\hline $\mathrm{H}$ & -0.07064900 & 4.78146800 & 10.47695700 \\
\hline
\end{tabular}




$\begin{array}{lrrr}\mathrm{C} & -0.99516700 & 3.15116700 & 9.28657000 \\ \mathrm{H} & -1.21679600 & 2.33729900 & 9.96028800 \\ \mathrm{C} & -6.27319900 & 6.46331400 & 4.53182000 \\ \mathrm{C} & -6.40985000 & 7.72826700 & 3.92948800 \\ \mathrm{H} & -5.53077800 & 8.35287700 & 3.78412000 \\ \mathrm{C} & -7.63529500 & 8.21060300 & 3.47392700 \\ \mathrm{H} & -7.68580700 & 9.19845300 & 3.01841500 \\ \mathrm{C} & -8.79882900 & 7.44144800 & 3.57878700 \\ \mathrm{C} & -8.67508500 & 6.16349700 & 4.13162300 \\ \mathrm{H} & -9.55312300 & 5.52305100 & 4.19993700 \\ \mathrm{C} & -7.44588100 & 5.69023300 & 4.58966600 \\ \mathrm{H} & -7.40158200 & 4.67749300 & 4.98304200 \\ \mathrm{C} & -10.13165700 & 7.97286200 & 3.12135900 \\ \mathrm{H} & -10.02227100 & 8.65644900 & 2.27220700 \\ \mathrm{H} & -10.80557600 & 7.16350200 & 2.82041500 \\ \mathrm{H} & -10.63218900 & 8.53107600 & 3.92406000 \\ \mathrm{C} & -2.39306800 & 0.64433100 & 8.09745100 \\ \mathrm{C} & -3.55947700 & -0.13958300 & 8.08376000 \\ \mathrm{H} & -4.44251000 & 0.22434000 & 7.56336200 \\ \mathrm{C} & -3.62290600 & -1.39162700 & 8.69470300 \\ \mathrm{H} & -4.55065300 & -1.96031000 & 8.65400800 \\ \mathrm{C} & -2.51412600 & -1.93334400 & 9.35177200 \\ \mathrm{C} & -1.33313500 & -1.18357700 & 9.34491700 \\ \mathrm{H} & -0.44051900 & -1.58728800 & 9.82053700 \\ \mathrm{C} & -1.27636500 & 0.06407600 & 8.72693500 \\ \mathrm{H} & -0.32230900 & 0.58772000 & 8.71726400 \\ \mathrm{C} & -2.58900500 & -3.26733600 & 10.04692300 \\ \mathrm{H} & -2.85159100 & -3.14825000 & 11.10679100 \\ \mathrm{H} & -3.34918400 & -3.91365100 & 9.59508000 \\ \mathrm{H} & -1.62948600 & -3.79480500 & 10.00905700 \\ \mathrm{~N} & -3.70345900 & 3.89612900 & 6.18282100 \\ \mathrm{~N} & -2.94082400 & 4.83102700 & 3.46774100 \\ \mathrm{~N} & -4.20384000 & 5.31100300 & 3.57323300 \\ \mathrm{~N} & -2.53443000 & 6.72022800 & 5.64142800 \\ \mathrm{~N} & -3.85344200 & 6.98385400 & 5.48589800 \\ \mathrm{~N} & -1.28861800 & 2.54951600 & 4.93747600 \\ \mathrm{~N} & -1.68804200 & 1.63871600 & 5.85577100 \\ \mathrm{~N} & -0.95901300 & 4.21525600 & 7.35717400 \\ \mathrm{~N} & -1.28892400 & 3.05348300 & 7.97507400 \\ \mathrm{H} & -1.19602800 & 7.35334100 & 2.70667800 \\ \mathrm{H} & -1.59003300 & 4.71653000 & 5.23891200 \\ \mathrm{H} & -0.85886900 & 6.75733900 & 3.40921900 \\ \mathrm{H} & & 7.10740100 & 2.62684500\end{array}$




\begin{tabular}{|c|c|c|c|}
\hline \multicolumn{4}{|c|}{$\mathrm{Sc}-\mathrm{O}-\mathrm{Sc}$} \\
\hline B & 4.41328200 & 6.02429100 & 5.01049500 \\
\hline B & 3.77195700 & 2.48239500 & 1.30159000 \\
\hline $\mathrm{C}$ & 5.01056000 & 5.23923800 & 3.70544200 \\
\hline $\mathrm{C}$ & 6.19571400 & 5.67506800 & 3.09958500 \\
\hline $\mathrm{H}$ & 6.75447500 & 6.49100000 & 3.54532300 \\
\hline $\mathrm{C}$ & 6.62865200 & 5.09518600 & 1.91518900 \\
\hline $\mathrm{H}$ & 7.52965900 & 5.45197200 & 1.41984500 \\
\hline $\mathrm{C}$ & 5.89172400 & 4.04974500 & 1.37629200 \\
\hline $\mathrm{H}$ & 6.20769300 & 3.57501600 & 0.45355900 \\
\hline $\mathrm{C}$ & 4.71240500 & 3.62432300 & 2.00068500 \\
\hline $\mathrm{C}$ & 2.19584800 & 3.60762300 & 6.69965100 \\
\hline $\mathrm{H}$ & 1.33399800 & 2.95771900 & 6.63523200 \\
\hline $\mathrm{C}$ & 3.01593100 & 3.89435100 & 7.79142200 \\
\hline $\mathrm{H}$ & 2.95439400 & 3.49906100 & 8.79481900 \\
\hline $\mathrm{C}$ & 3.92978600 & 4.81361300 & 7.29851800 \\
\hline $\mathrm{H}$ & 4.74625400 & 5.31890300 & 7.79014200 \\
\hline $\mathrm{C}$ & 1.65224700 & 7.50812300 & 3.10458100 \\
\hline $\mathrm{H}$ & 0.74030400 & 7.33353600 & 2.54984500 \\
\hline $\mathrm{C}$ & 2.34641000 & 8.69885600 & 3.32220400 \\
\hline $\mathrm{H}$ & 2.10796200 & 9.68750500 & 2.95798700 \\
\hline $\mathrm{C}$ & 3.41877900 & 8.32467000 & 4.12081200 \\
\hline $\mathrm{H}$ & 4.23150600 & 8.91186200 & 4.52059600 \\
\hline $\mathrm{C}$ & 1.79147200 & 1.05131700 & 4.06726500 \\
\hline $\mathrm{H}$ & 1.09368300 & 1.21994900 & 4.87585600 \\
\hline $\mathrm{C}$ & 2.35393700 & -0.14131700 & 3.61128600 \\
\hline $\mathrm{H}$ & 2.20766700 & -1.13929600 & 3.99790300 \\
\hline $\mathrm{C}$ & 3.14428200 & 0.24356800 & 2.53878300 \\
\hline $\mathrm{H}$ & 3.76094300 & -0.34597300 & 1.87880200 \\
\hline $\mathrm{C}$ & 1.12060900 & 4.85072000 & 0.39438500 \\
\hline $\mathrm{H}$ & 0.34512300 & 5.51712600 & 0.74697900 \\
\hline $\mathrm{C}$ & 1.54359800 & 4.58914700 & -0.90909900 \\
\hline $\mathrm{H}$ & 1.18245400 & 5.02568500 & -1.82884100 \\
\hline $\mathrm{C}$ & 2.53539300 & 3.62904700 & -0.75760600 \\
\hline $\mathrm{H}$ & 3.15518100 & 3.14182000 & -1.49495400 \\
\hline $\mathrm{C}$ & 5.48912400 & 6.82525600 & 5.92418300 \\
\hline $\mathrm{C}$ & 5.11515600 & 7.91230200 & 6.73556400 \\
\hline $\mathrm{H}$ & 4.09066100 & 8.27781600 & 6.70546400 \\
\hline $\mathrm{C}$ & 6.00379900 & 8.52832700 & 7.61518200 \\
\hline $\mathrm{H}$ & 5.66402100 & 9.36885000 & 8.21854600 \\
\hline $\mathrm{C}$ & 7.32045700 & 8.07586500 & 7.74706800 \\
\hline $\mathrm{C}$ & 7.69817100 & 6.96830800 & 6.98177500 \\
\hline $\mathrm{H}$ & 8.70613900 & 6.56824300 & 7.08093700 \\
\hline $\mathrm{C}$ & 6.80478900 & 6.36169900 & 6.09986800 \\
\hline $\mathrm{H}$ & 7.14211300 & 5.48708800 & 5.54852800 \\
\hline $\mathrm{C}$ & 8.29458300 & 8.75924500 & 8.67035400 \\
\hline
\end{tabular}




\begin{tabular}{|c|c|c|c|}
\hline $\mathrm{H}$ & 7.78309400 & 9.23276300 & 9.51549100 \\
\hline $\mathrm{H}$ & 9.03068000 & 8.05407800 & 9.07177700 \\
\hline $\mathrm{H}$ & 8.85271200 & 9.54681100 & 8.14611900 \\
\hline $\mathrm{C}$ & 4.51997200 & 1.44967800 & 0.29679400 \\
\hline $\mathrm{C}$ & 5.84865300 & 1.04021800 & 0.50568100 \\
\hline $\mathrm{H}$ & 6.42399100 & 1.48251800 & 1.31557500 \\
\hline $\mathrm{C}$ & 6.45864000 & 0.05924900 & -0.27494400 \\
\hline $\mathrm{H}$ & 7.49062300 & -0.22172700 & -0.07007800 \\
\hline $\mathrm{C}$ & 5.76674200 & -0.57575900 & -1.31082900 \\
\hline $\mathrm{C}$ & 4.43124700 & -0.21094500 & -1.50878600 \\
\hline $\mathrm{H}$ & 3.85048900 & -0.70738400 & -2.28485000 \\
\hline $\mathrm{C}$ & 3.82715400 & 0.76636200 & -0.71963200 \\
\hline $\mathrm{H}$ & 2.77353900 & 0.97964300 & -0.88784400 \\
\hline $\mathrm{C}$ & 6.43467800 & -1.60521200 & -2.18392700 \\
\hline $\mathrm{H}$ & 7.21419900 & -2.14976800 & -1.63982600 \\
\hline $\mathrm{H}$ & 5.71434700 & -2.33670600 & -2.56631000 \\
\hline $\mathrm{H}$ & 6.91397600 & -1.13650400 & -3.05407900 \\
\hline $\mathrm{N}$ & 4.27105100 & 4.26170700 & 3.11763100 \\
\hline $\mathrm{N}$ & 2.59561600 & 4.29862400 & 5.62554100 \\
\hline $\mathrm{N}$ & 3.66003300 & 5.04615800 & 5.99615100 \\
\hline $\mathrm{N}$ & 2.26558600 & 6.48984900 & 3.72390900 \\
\hline $\mathrm{N}$ & 3.34137000 & 7.00252600 & 4.36772600 \\
\hline $\mathrm{N}$ & 2.22005600 & 2.07963100 & 3.32565500 \\
\hline $\mathrm{N}$ & 3.04937200 & 1.58093300 & 2.38049300 \\
\hline $\mathrm{N}$ & 1.81327200 & 4.10642100 & 1.26804600 \\
\hline $\mathrm{N}$ & 2.66714400 & 3.33764600 & 0.55106400 \\
\hline $\mathrm{Sc}$ & 1.86628800 & 4.26384600 & 3.52780700 \\
\hline B & -4.41135500 & 6.02577800 & 2.66924400 \\
\hline B & -3.77366200 & 2.48787500 & 6.38256700 \\
\hline $\mathrm{C}$ & -5.00950700 & 5.24279400 & 3.97513400 \\
\hline $\mathrm{C}$ & -6.19440400 & 5.68038400 & 4.58023300 \\
\hline $\mathrm{H}$ & -6.75242000 & 6.49621300 & 4.13337200 \\
\hline $\mathrm{C}$ & -6.62803700 & 5.10236700 & 5.76528600 \\
\hline $\mathrm{H}$ & -7.52882800 & 5.46054100 & 6.26002000 \\
\hline $\mathrm{C}$ & -5.89209300 & 4.05698000 & 6.30563400 \\
\hline $\mathrm{H}$ & -6.20860500 & 3.58366400 & 7.22890600 \\
\hline $\mathrm{C}$ & -4.71302900 & 3.62977900 & 5.68198000 \\
\hline $\mathrm{C}$ & -2.19533300 & 3.60543600 & 0.98347400 \\
\hline $\mathrm{H}$ & -1.33398100 & 2.95496900 & 1.04883500 \\
\hline $\mathrm{C}$ & -3.01495800 & 3.89148500 & -0.10881700 \\
\hline $\mathrm{H}$ & -2.95349800 & 3.49495500 & -1.11172800 \\
\hline $\mathrm{C}$ & -3.92823900 & 4.81200400 & 0.38280000 \\
\hline $\mathrm{H}$ & -4.74424000 & 5.31729700 & -0.10959700 \\
\hline $\mathrm{C}$ & -1.64968300 & 7.50979700 & 4.57403900 \\
\hline $\mathrm{H}$ & -0.73799500 & 7.33515200 & 5.12917900 \\
\hline $\mathrm{C}$ & -2.34290900 & 8.70079600 & 4.35488800 \\
\hline
\end{tabular}




$\begin{array}{lrrr}\mathrm{H} & -2.10381600 & 9.68968300 & 4.71803400 \\ \mathrm{C} & -3.41538200 & 8.32648900 & 3.55647200 \\ \mathrm{H} & -4.22758600 & 8.91382400 & 3.15583800 \\ \mathrm{C} & -1.79394600 & 1.05196100 & 3.61880600 \\ \mathrm{H} & -1.09589800 & 1.21906600 & 2.81012000 \\ \mathrm{C} & -2.35749300 & -0.13966700 & 4.07607000 \\ \mathrm{H} & -2.21204600 & -1.13820800 & 3.69059700 \\ \mathrm{C} & -3.14765300 & 0.24712000 & 5.14802300 \\ \mathrm{H} & -3.76491000 & -0.34113700 & 5.80859100 \\ \mathrm{C} & -1.12029100 & 4.85478500 & 7.28753400 \\ \mathrm{H} & -0.34416000 & 5.52009800 & 6.93429300 \\ \mathrm{C} & -1.54366100 & 4.59501200 & 8.59125100 \\ \mathrm{H} & -1.18221400 & 5.03220800 & 9.51056200 \\ \mathrm{C} & -2.53633800 & 3.63567500 & 8.44069100 \\ \mathrm{H} & -3.15665200 & 3.14982300 & 9.17850600 \\ \mathrm{C} & -5.48647700 & 6.82634000 & 1.75436100 \\ \mathrm{C} & -5.11173700 & 7.91223500 & 0.94180100 \\ \mathrm{H} & -4.08705300 & 8.27723600 & 0.97169300 \\ \mathrm{C} & -5.99985200 & 8.52771300 & 0.06125900 \\ \mathrm{H} & -5.65948200 & 9.36734500 & -0.54301100 \\ \mathrm{C} & -7.31672100 & 8.07581000 & -0.07040100 \\ \mathrm{C} & -7.69521500 & 6.96935600 & 0.69611100 \\ \mathrm{H} & -8.70337900 & 6.56972400 & 0.59719400 \\ \mathrm{C} & -6.80236200 & 6.36329900 & 1.57892600 \\ \mathrm{~N} & -7.14029300 & 5.48953300 & 2.13123200 \\ \mathrm{H} & -8.29027700 & 8.75862300 & -0.99470700 \\ \mathrm{C} & -3.59481100 & 4.29800200 & 2.05668100 \\ \mathrm{H} & -7.77830000 & 9.23129500 & -1.84002000 \\ \mathrm{H} & -9.02636200 & 8.05328300 & -1.39585200 \\ \mathrm{H} & -8.84846100 & 9.54676200 & -0.47139300 \\ \mathrm{C} & -4.52271300 & 1.45692900 & 7.38840700 \\ \mathrm{C} & -5.85172900 & 1.04841300 & 7.17985100 \\ \mathrm{H} & -6.42660400 & 1.49031300 & 6.36941100 \\ \mathrm{C} & -6.46264600 & 0.06883300 & 7.96150700 \\ \mathrm{H} & -7.49485500 & -0.21146800 & 7.75685600 \\ \mathrm{C} & -5.77140800 & -0.56563300 & 8.99815400 \\ \mathrm{H} & -4.43560600 & -0.20176600 & 9.19584200 \\ \mathrm{H} & -3.85534900 & -0.69785300 & 9.97250700 \\ \mathrm{H} & -3.83058900 & 0.77413100 & 8.40566300 \\ \mathrm{H} & -2.77680200 & 0.98667400 & 8.57372700 \\ \mathrm{H} & -5.44029900 & -1.59353700 & 9.87234400 \\ \mathrm{H} & -22153100 & -2.13671500 & 9.32933400 \\ \mathrm{H} & -2.31759900 & -1.12365400 & 10.74295900 \\ \mathrm{H} & -3.04590800 & 1.68494700\end{array}$




$\begin{array}{lrrr}\mathrm{N} & -2.26365100 & 6.49127000 & 3.95575000 \\ \mathrm{~N} & -3.33889900 & 7.00400900 & 3.31109200 \\ \mathrm{~N} & -2.22174500 & 2.08149400 & 4.35917800 \\ \mathrm{~N} & -3.05162700 & 1.58458200 & 5.30480000 \\ \mathrm{~N} & -1.81356800 & 4.11019300 & 6.41460300 \\ \mathrm{~N} & -2.66824000 & 3.34300800 & 7.13232200 \\ \mathrm{O} & 0.00016900 & 4.28285900 & 3.84157800 \\ \mathrm{Sc} & -1.86606800 & 4.26520500 & 4.15467300\end{array}$

\section{Orbital Information of $\left(\mathrm{B}_{2} \mathbf{P z}_{4} \mathbf{P y}\right) \operatorname{ScOSc}\left(\mathrm{B}_{2} \mathbf{P z}_{4} \mathbf{P y}\right)$}

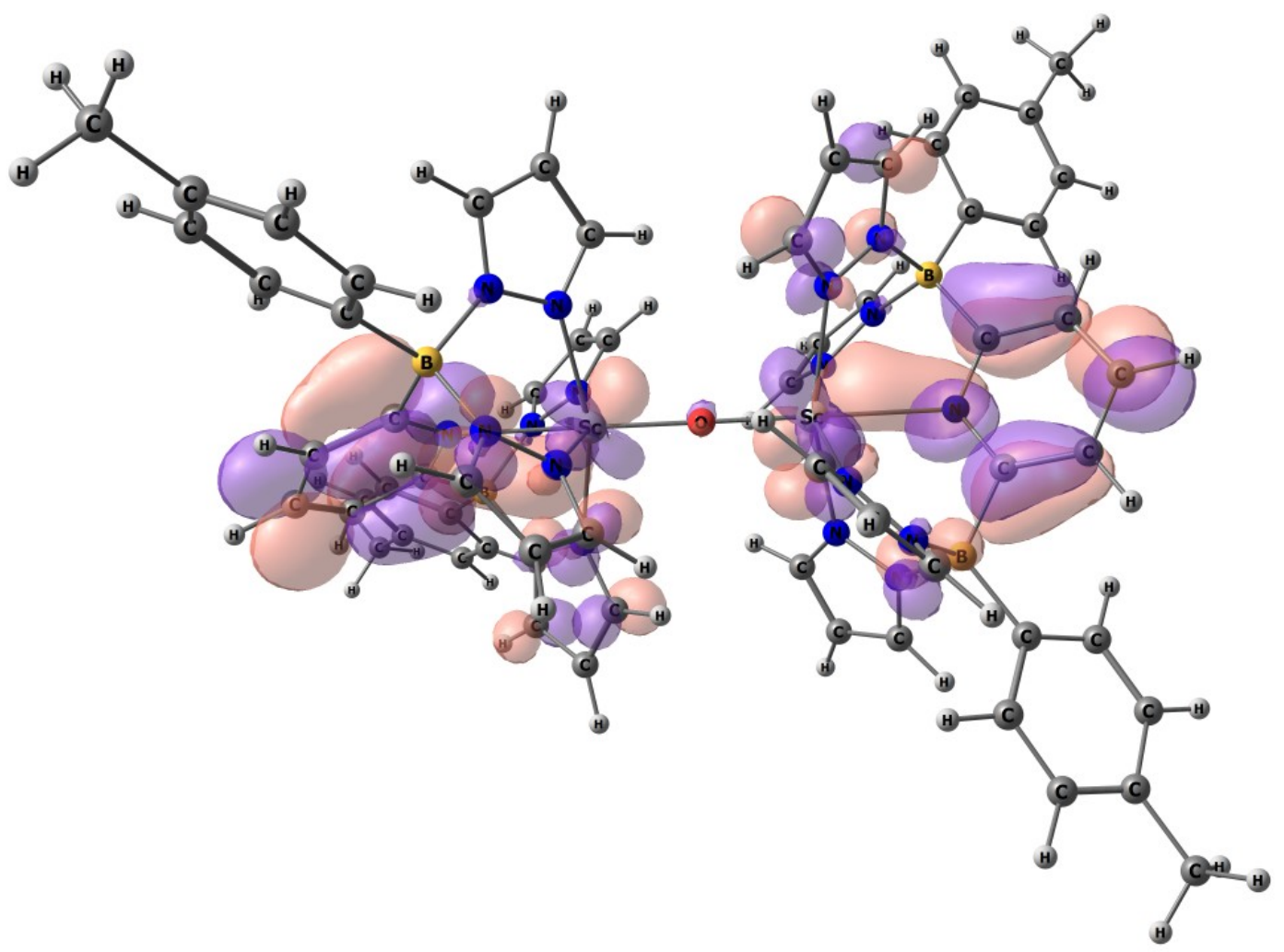

Figure S11 Depiction of the LUMO (orbital 304) of ScOSc. Energy: -0,89407 eV. 


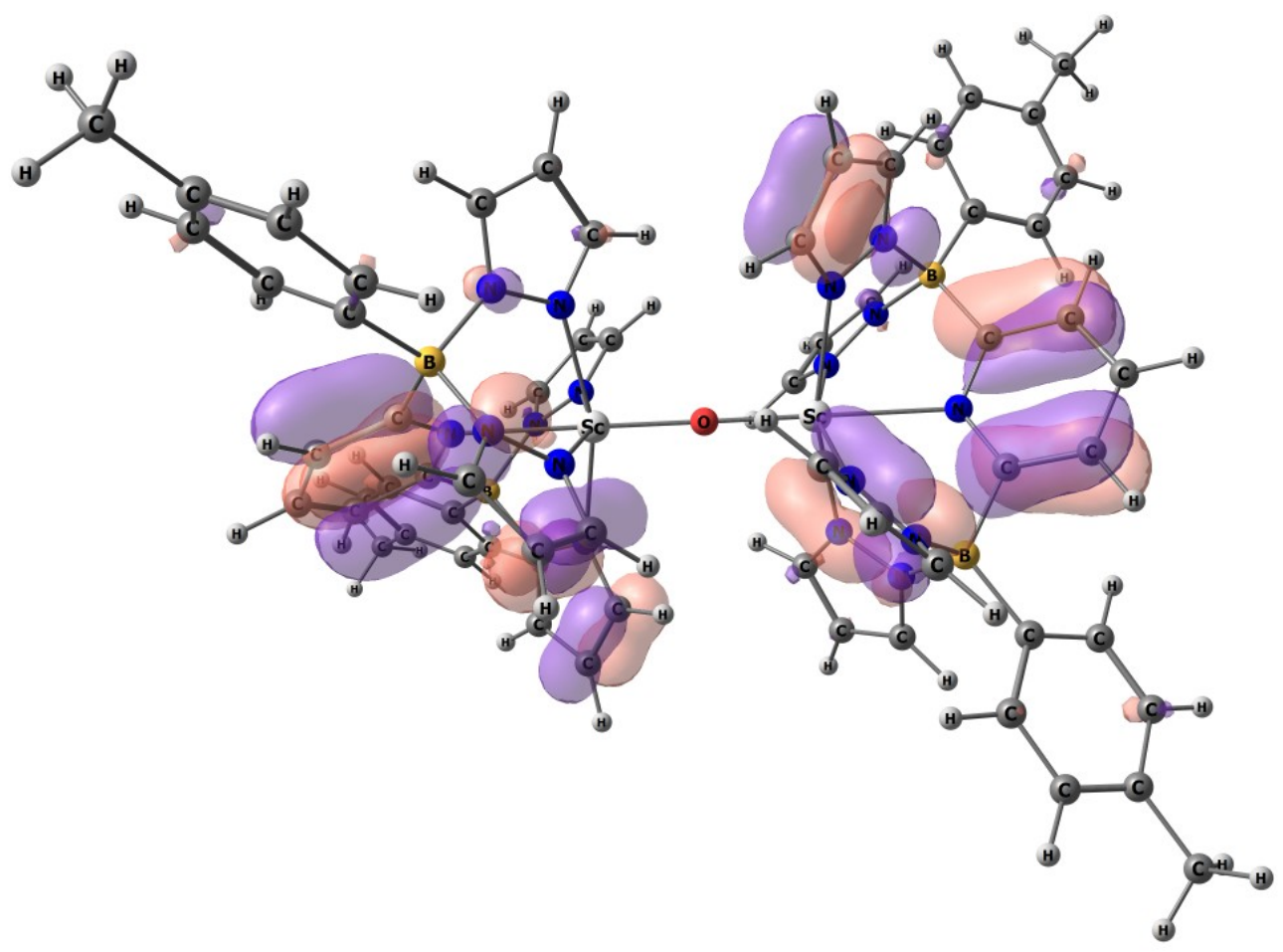

Figure S12 Depiction of the HOMO (orbital 303) of ScOSc. Energy: -6,26396 eV.

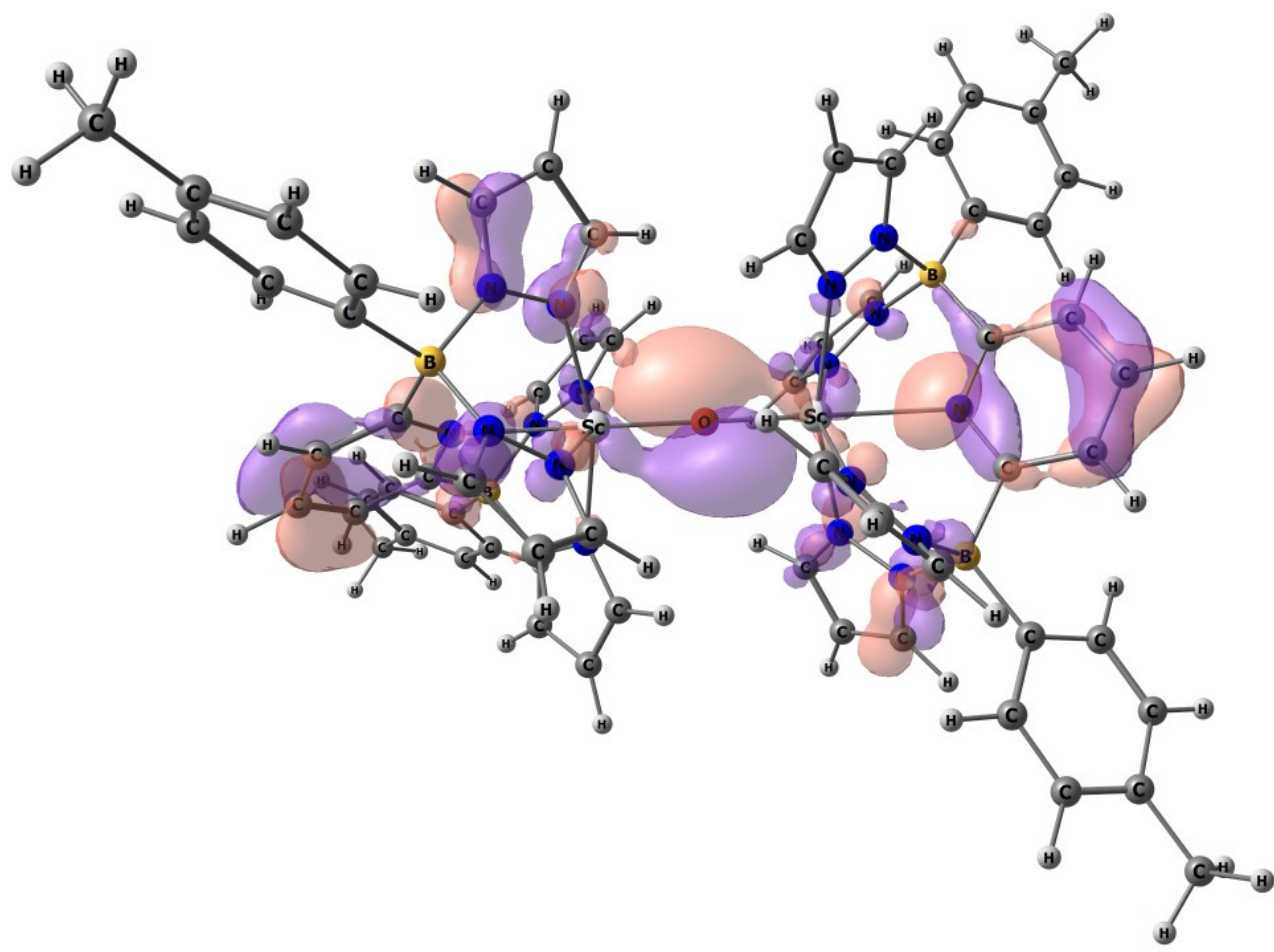

Figure S13 Depiction of the HOMO-28 (orbital 275) of ScOSc. Energy: -7,61458 eV. 


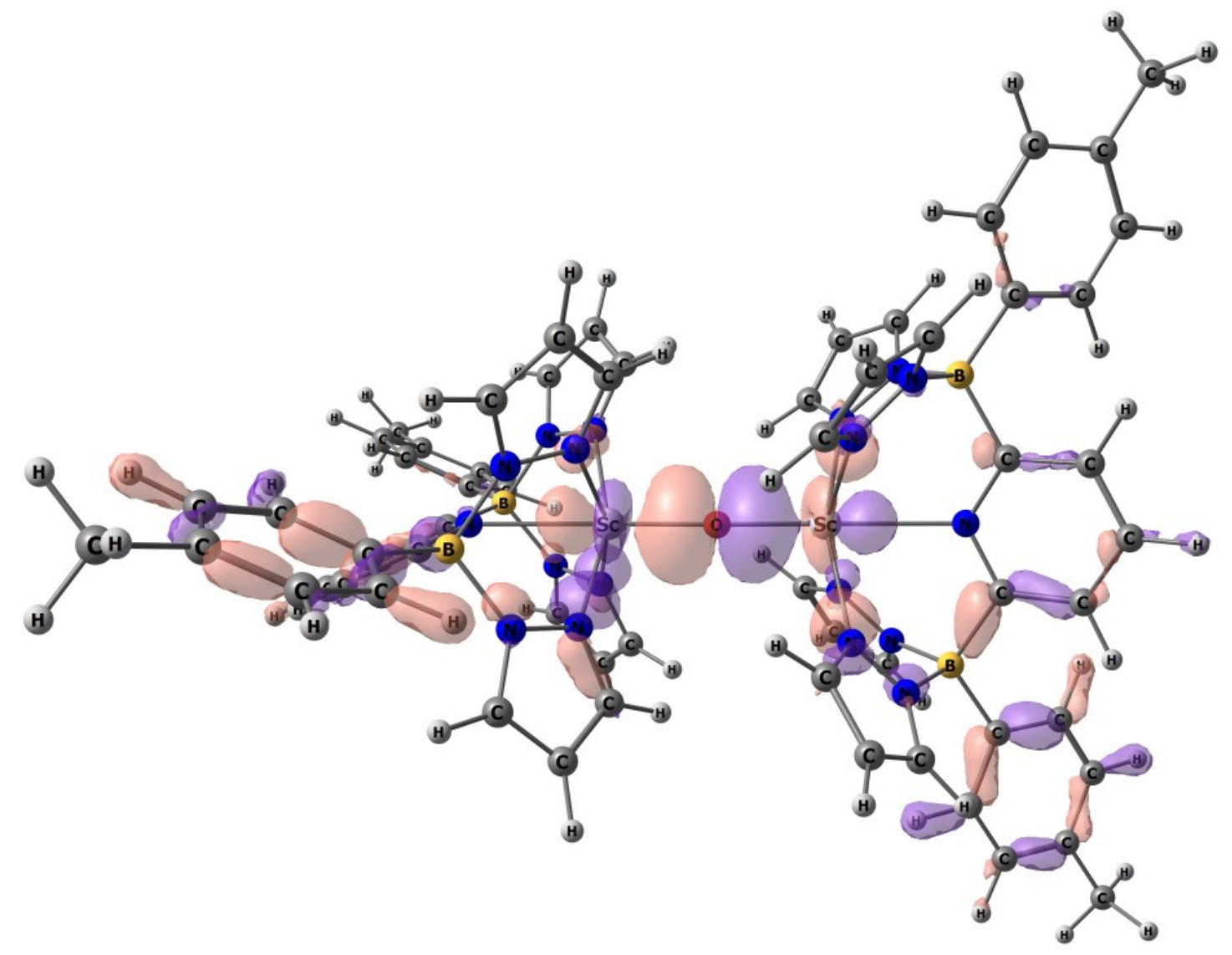

Figure S14 Depiction of the HOMO-38 (orbital 265) of ScOSc. Energy: -8,62823 eV.

Second Order Donor Acceptor

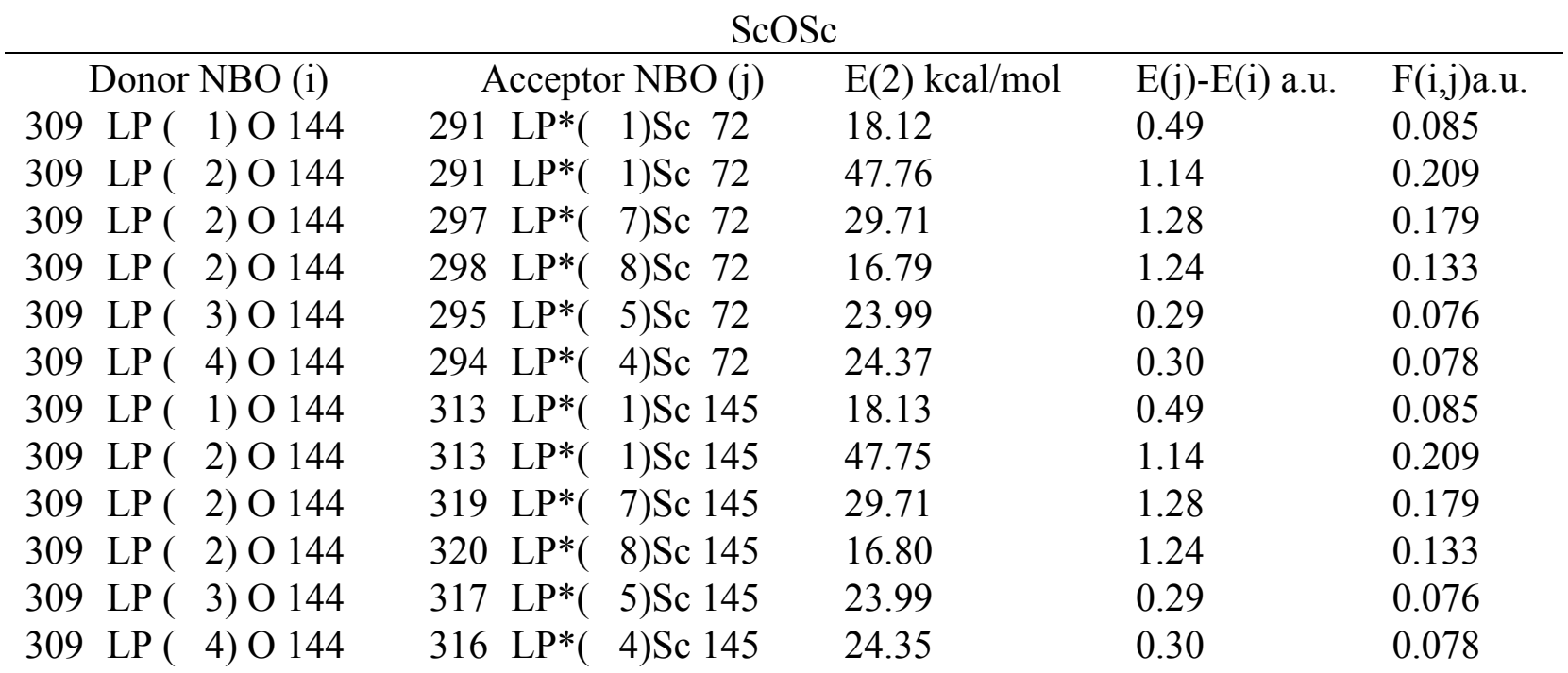




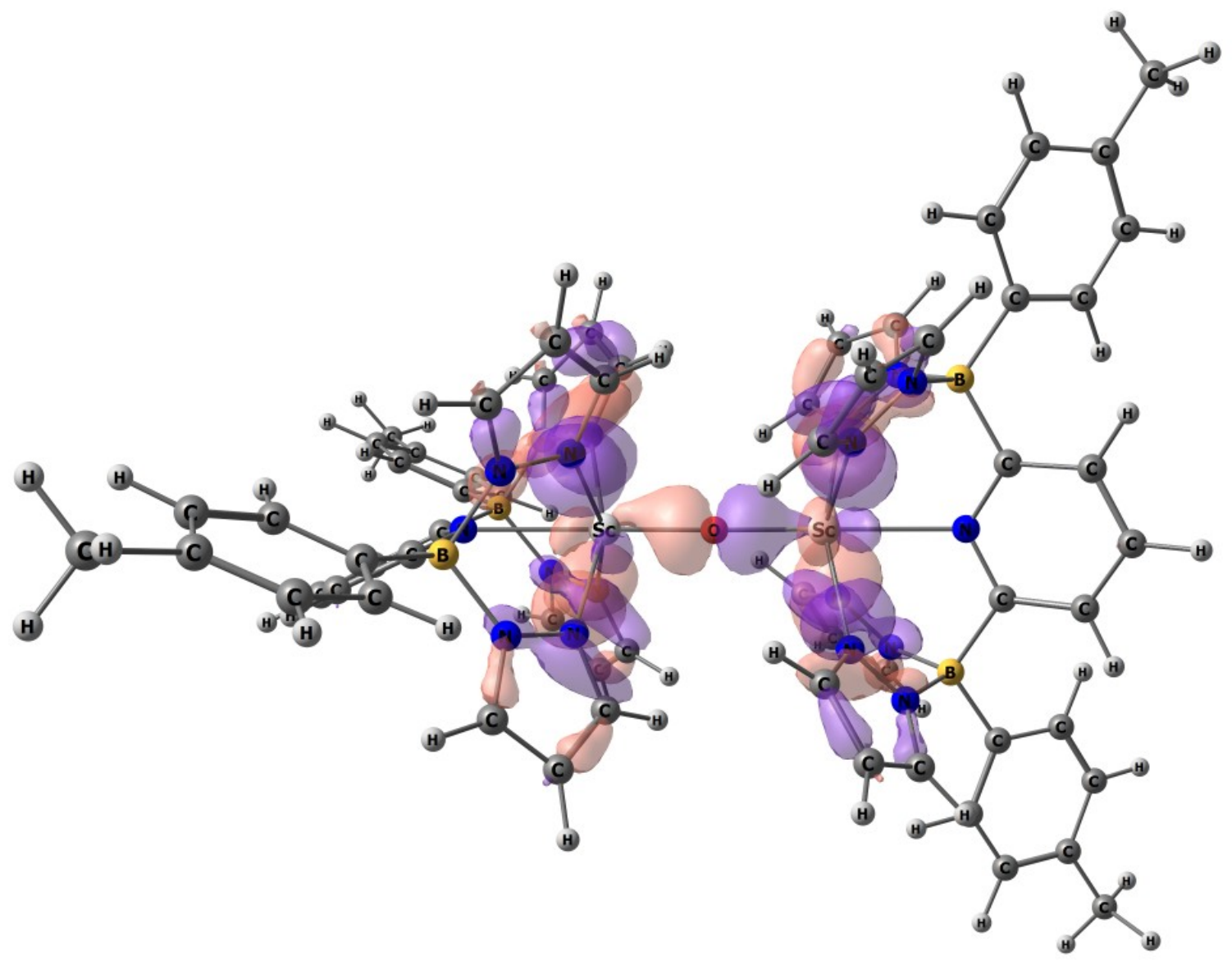

Figure S15 Depiction of the HOMO-40 (orbital 263) of ScOSc. Energy: -8,66084 eV. 


\section{References}

[1] Pangborn, A. B.; Giardello, M. A.; Grubbs, R. H.; Rosen, R. K.; Timmers, F. J. Organometallics 1996, 15, 1518-1520.

[2] Beh, D. W.; Piers, W. E.; del Rosal, I.; Maron, L.; Gelfand, B. S.; Gendy, C.; Lin, J.-B. Dalton Trans. 2018, 47, 13680-13688.

[3] Fulmer, G. R.; Miller, A. J. M.; Sherden, N. H.; Gottlieb, H. E.; Nudelman, A.; Stoltz, B. M.; Bercaw, J. E.; Goldberg, K. I. Organometallics 2010, 29, 2176-2179.

[4] Gaussian 09, Revision D.01, Frisch, M. J.; Trucks, G. W.; Schlegel, H. B.; Scuseria, G. E.; Robb, M. A.; Cheesman, J. R.; Scalmani, G.; Barone, V.; Mennucci, B.; Petersson, G. A.; Nakatsuji, H.; Caricato, M.; Li, X.; Hratchian, H. P.; Izmaylov, A. F.; Bloino, J.; Zheng, G.; Sonnenberg, J. L.; Hada, M.; Ehara, M.; Toyota, K.; Fukuda, R.; Hasegawa, J.; Ishida, M.; Nakajima, T.; Honda, Y.; Kitao, O.; Nakai, H.; Vreven, T.; Montgomery, J. A., Jr.; Peralta, J. E.; Ogliaro, F.; Bearpark, M.; Heyd, J. J.; Brothers, E.; Kudin, K. N.; Staroverov, V. N.; Kobayashi, R.; Normand, J.; Raghavachari, K.; A., R.; Burant, J. C.; Iyengar, S. S.; Tomasi, J.; Cossi, M.; Rega, N.; Millam, M. J.; Klene, M.; Knox, J. E.; Cross, J. B.; Bakken, V.; Adamo, C.; Jaramillo, J.; Gomperts, R.; Stratmann, R. E.; Yazyev, O.; Austin, A. J.; Cammi, R.; Pomelli, C.; Ochterski, J. W.; Martin, R. L.; Morokuma, K.; Zakrzewski, V. G.; Voth, G. A.; Salvador, P.; Dannenberg, J. J.; Dapprich, S.; Daniels, A. D.; Farkas, O.; Foresman, J. B.; Ortiz, J. V.; Cioslowski, J.; Fox, D. J., Gaussian Inc., 2009, Wallingford CT.

[5] (a) Becke, A. D. Density-Functional Thermochemistry. III. The Role of Exact Exchange. $J$. Chem. Phys. 1993, 98, 5648-5652 and references therein; (b) Burke, K.; Perdew, J. P.; Yang, W. Electronic Density Functional Theory: Recent Progress and New Directions; Plenum: New York, 1998.

[6] (a) Dolg, M. ; Wedig, H.; Stoll, H. ; Preuss, H. Energy adjusted ab initio pseudopotentials for the first row transition elements. J. Chem. Phys. 1987, 86, 866- 872; (b) Martin, J. M. L.; Sundermann, A. Correlation consistent valence basis sets for use with the Stuttgart-DresdenBonn relativistic effective core potentials: The atoms $\mathrm{Ga}-\mathrm{Kr}$ and $\mathrm{In}-\mathrm{Xe}$. J. Chem. Phys. 2001, $114,3408-3420$.

[7] (a) Hariharan, P. C.; Pople, J. A. The Influence of Polarization Functions on Molecular Orbital Hydrogenation Energies. Theor. Chem. Acc. 1973, 28, 213-222; (b) Hehre, W. J.; Ditchfield, R.; Pople, J. A. Self-Consistent Molecular Orbital Methods. XII. Further Extensions of Gaussian-Type Basis Sets for Use in Molecular Orbital Studies of Organic Molecules. $J$. Chem. Phys. 1972, 56, 2257-2261. 